\title{
Genomic and Transcriptomic Characterization of the New Human Glioblastoma Cell Line AHOL1
}

Wallax Augusto Silva Ferreira'; Carolina Koury Nassar Amorim; Rommel Rodriguez Burbano $^{2,3,4}$; Rolando André Rios Villacis ${ }^{5}$; Fabio Albuquerque Marchi ${ }^{6}$; Tiago da Silva Medina $^{6}$; Edivaldo Herculano Correa de Oliveira ${ }^{1,7^{*}}$.

${ }^{1}$ Laboratório de Cultura de Tecidos e Citogenética, SAMAM, Instituto Evandro Chagas, 67030-000,

Ananindeua, PA, Brazil.

${ }^{2}$ Laboratório de Citogenética Humana, Instituto de Ciências Biológicas, Universidade Federal do Pará (UFPA), 66075-110, Belém, Pará, Brazil.

${ }^{3}$ Núcleo de Pesquisas em Oncologia, Hospital Universitário João de Barros Barreto, 66.073-000, Belém, Pará, Brazil.

${ }^{4}$ Laboratório de Biologia Molecular, Hospital Ophir Loyola, 66063-240, Belém, Pará, Brazil.

${ }^{5}$ Department of Genetics and Morphology, Institute of Biological Sciences, University of Brasília-UnB, Brasília 70910-900, Brazil.

${ }^{6}$ International Research Center (CIPE), A.C. Camargo Cancer Center, 01508-010, São Paulo, Brazil.

${ }^{7}$ Instituto de Ciências Exatas e Naturais, Faculdade de Ciências Naturais, Universidade Federal do Pará (UFPA), 66075-110, Belém, Pará, Brazil.

*Corresponding author

Dr. Edivaldo Herculano Correa de Oliveira

Laboratório de Cultura de Tecidos e Citogenética, SAMAM, Instituto Evandro Chagas, Rodovia BR-316 km 7, s/n, Levilândia, 67030-000, Ananindeua, Pará, Brasil.

E-mail: edivaldodeoliveira@iec.pa.gov.br 


\begin{abstract}
Cancer cell lines are widely used as in vitro models of tumorigenesis, facilitating fundamental discoveries in cancer biology and translational medicine. Currently, there are few options for glioblastoma (GBM) treatment and limited in vitro models with accurate genomic and transcriptomic characterization. Here, a detailed characterization of a new GBM cell line, namely AHOL1, was conducted in order to fully characterize its molecular composition based on its copy number alteration (CNA) and transcriptome profiling, followed by the validation of key elements associated with GBM tumorigenesis. Large numbers of CNAs and differentially expressed genes (DEGs) were identified. CNAs were distributed throughout the genome, including gains at Xq11.1q28, Xp22.33-p11.1, Xq21.1-q21.33, 4p15.1-p14, 8q23.2-q23.3 and losses at Yq11.21q12, Yp11.31-p11.2 and 12p13.31 positions. Nine druggable genes were identified, including HCRTR2, ETV1, PTPRD, PRKX, STS, RPS6KA6, ZFY, USP9Y and KDM5D. By integrating DEGs and CNAs, we identified 57 overlapping genes enriched in fourteen pathways. Altered expression of several cancer-related candidates found in the DEGs-CNA dataset was confirmed by RT-qPCR. Taken together, this first comprehensive genomic and transcriptomic landscape of AHOL1 provides unique resources for further studies and identifies several druggable targets that may be useful for therapeutics and biologic and molecular investigation of GBM.
\end{abstract}

Keywords: array-comparative genomic, gliomas, Cell culture, Cancer genomics, Cancer Transcriptomics, brain tumors, cell line, glioblastoma. 


\section{INTRODUCTION}

Glioblastomas (also known as GBM or Glioblastoma Multiforme) are tumors that arise from the accumulation of somatic mutations in neural stem cells within the subventricular zone (SVZ) [1, 2]. They are the most lethal and common malignancy among all brain tumors, with incidence rate of 3.21 cases per 100.000 individuals, median survival rate of 12-18 months [3] and higher predominance in males [4]. GBMs are commonly diagnosed in elderly patients (median of 65 years) [3], increasing with age peaking at 75-84 years and declining after 85 years [4].

According to the new classification for Central Nervous System (CNS) tumors proposed by World Health Organization (WHO) in 2016, GBMs are classified as grade IV and included in diffuse astrocytic and oligodendroglial tumors [5]. Based on the mutational pattern of the isocitrate dehydrogenase $(I D H)$ gene, they are further classified as (a) $I D H$-wildtype GBM (90\% of cases), which frequently correspond to clinically defined primary GBM (or de novo GBM), arising predominately from supratentorial region in patients with median age of $\sim 62$ years at diagnosis and whose mean length of clinical history is 4 months; or (b) $I D H$-mutant-type GBM $(10 \%$ of cases), which are defined as secondary GBM preferentially arising from the frontal region of younger patients (median age at diagnosis of $\sim 44$ years) and whose prognosis is usually better than those with $I D H$-wildtype [5-8].

Currently, standard treatment for both GBM entities encompasses surgical resection followed by radiotherapy (RT) and chemotherapy (mainly using temozolomide - TMZ) [9-12]. However, these aggressive treatments are not effective in controlling the disease [13, 14], thus evidencing a high demand for new efficacious therapies to improve outcomes of patients with GBM [15].

In vitro cultures of GBM cell lines have been widely used as an important model for understanding GMB heterogeneity, drug sensitivity and resistance, evaluation of new therapeutic approaches and to search for novel biomarkers [16-20]. The Human Glioblastoma Cell Culture (HGCC) biobank has assembled a panel of 53 cell lines derived from surgical samples of GBM patients [21]. However, there is a limited number of GBM cell lines deposited in HGCC or other biobanks (Broad-Novartis Cancer Cell Line Encyclopedia and American Type Culture Collection), given the heterogeneity of each molecular subtype of GBM [22-29]. Thus, new, wellcharacterized cell lines that resemble these different molecular subtypes of GBM are still needed to better comprehend the molecular mechanisms involved in GBM 
tumorigenesis. To this end, the goal of this study was to characterize the molecular composition based on copy number alteration (CNA) and transcriptome profile of a newly established glioblastoma cell line, as a strategy to discover potential druggable targets that might prevent GBM development and progression.

\section{MATERIAL AND METHODS}

Study approval by the Research Ethics Committee and collection of non-neoplastic samples

This study was approved by the Research Ethics Committee of the Instituto Evandro Chagas/IEC/SVS/MS (Process Number 192.336). The use of the sample to establish the AHOL1 cell line was approved by the Research Ethics Committee of the Ophir Loyola Hospital, and a written informed consent was obtained from the patient.

Ten non-neoplastic samples from nervous tissue were obtained from biopsies of patients from Ophir Loyola Hospital, Belém, Pará, Brazil. All tissue samples were immediately frozen in liquid nitrogen and stored in DNA/RNA Shield ${ }^{\mathrm{TM}}$ (Zymo Research) at $-80^{\circ} \mathrm{C}$ until the extraction stage.

\section{Materials}

Dulbecco's modified Eagle's medium (DMEM), fetal bovine serum (FBS), Trypsin/EDTA, penicillin G and streptomycin were obtained from Gibco (Grand Island, NY, USA) and used to grow GBM cell lines in culture.

\section{Culture of human glioblastoma cell lines}

The main subject of this study was AHOL1 (Astrocytoma Ophir Loyola Hospital 1), a cell line established by our group at the Human Cytogenetics Laboratory, Federal University of Pará (UFPA), from a secondary GBM obtained from the tumor resection of a 43-year-old multiracial male patient treated in the Neurological Clinic of Ophir Loyola Hospital (Belém, PA, Brazil) with a histopathologic diagnosis of GBM (grade IV) that evolved from a grade III astrocytoma [30, 31]. As comparatives to common alterations observed in glioblastoma cell lines, we used three well stablished human glioblastoma cell lines in our experiments: U-343 MGa cell line kindly provided by the Cytogenetics and Mutagenesis Laboratory, University of São Paulo (Ribeirão 
Preto, SP, Brazil), derived from a primary GBM from a Caucasian adult patient and obtained from CLS Cell Lines Service (CLS order number 300365) [32], U-87 MG purchased from American Type Culture Collection (ATCC; Manassas, VA, USA) (catalog number $\mathrm{ATCC}^{\circledR}$ HTB-14 ${ }^{\mathrm{TM}}$ ) and $1321 \mathrm{~N} 1$ cell obtained from European Collection of Authenticated Cell Cultures (ECACC) (catalog number 86030402).

All cell lines were cultured separately in $25-\mathrm{cm}^{2}$ culture flasks using DMEM supplemented with $10 \%$ fetal bovine serum (FBS), $100 \mathrm{U} / \mathrm{mL}$ penicillin and $100 \mu \mathrm{g} / \mathrm{mL}$ streptomycin at $37{ }^{\circ} \mathrm{C}$ in a humidified $5 \% \mathrm{CO}_{2}$ atmosphere. The medium was changed every 2-3 days, and cells were sub-cultured when confluency reached $70-80 \%$ using $0.25 \%$ trypsin at $37^{\circ} \mathrm{C}$.

\section{Nucleic acids extraction}

When cells reached total confluence, they were washed with PBS, detached with $0.25 \%$ Trypsin/EDTA $\left(\right.$ Gibco $\left.^{\mathrm{TM}}\right)$, and suspended in PBS. DNA and RNA were extracted using the Wizard ${ }^{\circledR}$ Genomic DNA Purification Kit (Promega Corporation) and SV Total RNA Isolation System (Promega Corporation) respectively, according to the manufacturer's protocol.

DNA and RNA purity and integrity were assessed on the Agilent 2200 TapeStation (Agilent Technologies, Santa Clara, CA, USA) with D1000 ScreenTape (Agilent Technologies, Santa Clara, CA, USA) and High Sensitivity RNA ScreenTape (Agilent Technologies, Santa Clara, CA, USA) respectively, as previously described [33-35]. Only samples with DNA Integrity Number (DIN) and RNA integrity (RIN) $>7$ were used for downstream analyses.

\section{Array-Based Comparative Genomic Hybridization Analysis}

\section{Chromosomal Imbalances Analysis}

Array-CGH (aCGH) experiments were performed on an Agilent microarray platform (Agilent Technologies Inc., Santa Clara, CA USA) with a SurePrint G3 Cancer CGH+SNP Microarray 4x180K slide (Agilent). Sample preparation, labelling, and microarray hybridization were performed according to the Agilent CGH Enzymatic Protocol version 7.5. Slides were scanned using the Agilent G2565CA scanner. Data were extracted with Feature Extraction software (v9.1 Agilent Technologies) and 
analyzed with Genomic Work Bench 11.0.1, Agilent Cytogenomics 5.0 and GeneSpring GX 14.5. LogRatio $>0.25$ and $\log$ Ratio $<-0.25$ were defined as copy number gains and losses, respectively. The ideogram showing the CNAs identified in AHOL1 genome was constructed using the PhenoGram online software [36]. The CNAs information of 1087 cancer cell lines from CellMiner [37] and the Cancer Cell Line Encyclopedia (CCLE) [38], 1987 human GBMs from TCGA database [39-45], stored in the cBioPortal for Cancer Genomics (accessed in June 2019) [46], was used to explore the similarities with CNAs of AHOL1 cell line. Additionally, Candidate Cancer Gene Database (CCGD) was used to identify candidate cancer genes from CNAs of AHOL1 genome [47].

\section{Gene Expression Microarray}

Gene expression profiling analysis was performed using the Agilent Oligo Microarray Kit $8 \times 60 \mathrm{~K}$ according to the Agilent One-Color Microarray-based Gene Expression Analysis Protocol (Agilent Technologies, Santa Clara, CA, USA). Data were extracted with Feature Extraction software (v9.1 Agilent Technologies) and analyzed with GeneSpring software GX 14.5 (Agilent Technologies). Raw data were normalized by robust multiarray average (RMA) quantile normalization analysis algorithm with the GeneSpring GX 14.5 software (Agilent Technologies, Santa Clara, CA, US) to generate CEL intensity files. We performed the quality control following diagnostic plots: principal component analysis (PCA), boxplots, Pearson's correlation, and MvA plots.

Significantly differentially expressed genes (DEGs) were identified by using the mixed model analysis of variance [11] with a false discovery rate (FDR) cut-off $<$ 0.01 and absolute fold-change values $\geq 2$. Gene ontology enrichment analysis was performed using DAVID (Database for Annotation, Visualization and Integration Discovery) Bioinformatic tools. Pathway enrichment analysis was performed by using the KEGG database and PANTHER (http://www.pantherdb.org/).

\section{Integrative analysis of CNAs and DEGs}

To identify the significant genes that exhibited CNA and gene expression alterations, we integrated the significant CNAs and DEGs using GeneSpring software GX 14.5 (Agilent Technologies) as described elsewhere. [48]. 


\section{Search for drugs targeting CNAs}

The Drug-Gene Interaction Database (DGIdb) [49, 50] was used to search potential drugs targeting CNAs. This database provides gene druggability information from databases (such as therapeutic target database [51]; DrugBank [52]; pharmacogenomics knowledge database [53]), papers and web resources [50].

\section{Reverse transcription qPCR $(R T-q P C R)$}

For the cDNA synthesis, we used the GoScript ${ }^{\mathrm{TM}}$ Reverse Transcription System (Promega Corporation) following the manufacturer's instructions. Real time PCR (qPCR) was performed as described by Ferreira et al. [54], using GoTaq ${ }^{\circledR}$ Probe qPCR Master Mix (Promega Corporation). All reactions were carried out in triplicate in 96well PCR plates, using CFX96 Touch ${ }^{\mathrm{TM}}$ Real-Time PCR Detection System (Bio-Rad). Data analysis was performed using the Bio-Rad CFX Manager ${ }^{\mathrm{TM}} 3.1$ software (BioRad). Following the MIQE guidelines [55], the expression levels were normalized using $T B P$ and $G A P D H$ in non-neoplastic samples. The relative gene expression was

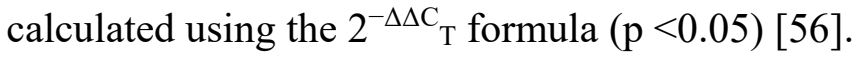

The expression of the genes ANOS1, ETV1, XPNPEP2 and PCDH11Y was quantitated using Taqman ${ }^{\circledR}$ gene expression assays (Applied Biosystems, Foster City, CA, USA) (Table 1).

Table 1. Targets and housekeeping genes used in this study.

\begin{tabular}{ccc}
\hline Official Gene Symbol* & Official Full Name* $^{*}$ & Assay ID \\
\hline$G A P D H$ & Glyceraldehyde-3-phosphate dehydrogenase & Hs02786624_g1 \\
$T B P$ & TATA-box binding protein & Hs00427620_m1 \\
$A N O S 1$ & Anosmin 1 & Hs01085107_m1 \\
$E T V 1$ & ETS variant 1 & Hs00951951_m1 \\
$X P N P E P 2$ & X-prolyl aminopeptidase 2 & Hs00950918_m1 \\
$P C D H 11 Y$ & Protocadherin 11 Y-linked & Hs06651077_g1 \\
\hline
\end{tabular}

* Official symbols and names of the genes were based on HUGO gene nomenclature committee (HGNC).

\section{RESULTS}

CNA profiling of AHOL1 cell line

A global view of the AHOL1 CNAs composition was generated using the aCGH results. A total of 19 CNAs (17 gains and 2 losses) were identified, ranging from 
$0.28 \mathrm{Mb}$ to $93 \mathrm{Mb}$. A full list of the CNAs and their corresponding chromosome localization, cytobands, type of alteration, $\mathrm{p}$ value and genes are provided in Table S1. Copy number gains were located at chromosomes 4, 6, 7, 8, 9, 10, 11, 14, 17 and 19, while losses at chromosome 15 (Figure 1; Table S1). Whole chromosome gains and losses were observed at chromosomes $\mathrm{X}$ and $\mathrm{Y}$, respectively.

The highest number of gains was found at chr X at q11.1-q28 $(93,148.679 \mathrm{~kb}$ - with 3016 segments), p22.33 - p11.1 (55,799.123 kb - with 1745 segments) and q21.1 - q21.33 $(13,545,889 \mathrm{~kb})$ positions. The second highest number of gains was documented at chromosome 4 (cytoband p15.1 - p14) corresponding to 7,800 kb, followed by chromosome 8 (cytoband q23.2 - q23.3) corresponding to 5,104 kb.

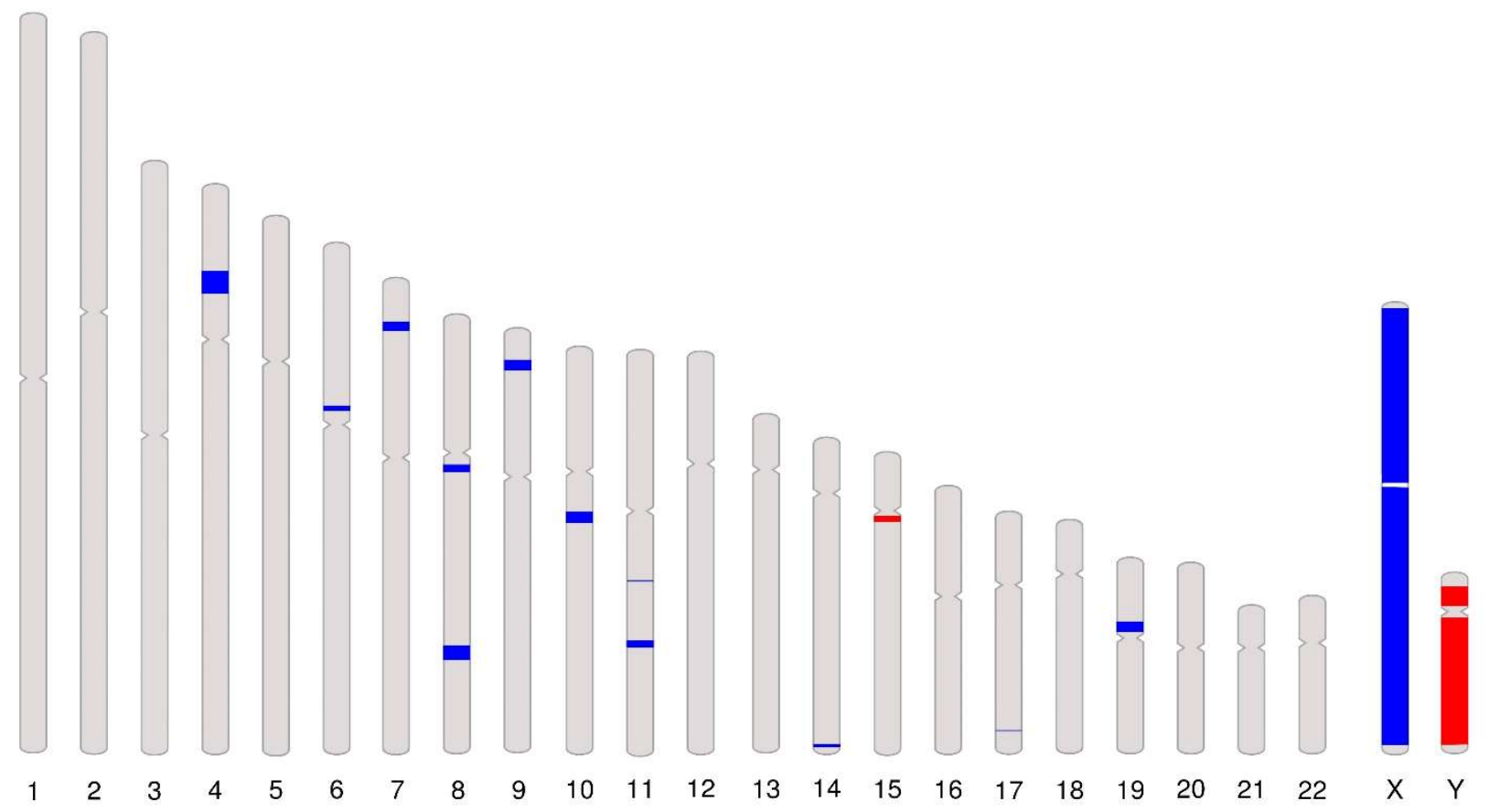

Additionally, we identified that the highest frequency of losses occurred on the $\mathrm{Y}$ chromosome at q11.21 - q12 (45,327.039 kb) and p11.31 - p11.2 (7,119.122 kb) positions (Figure 1).

Figure 1. Representative CNAs (ideogram) showing gains (blue), and losses (red) in the AHOL1 genome.

We further explored whether AHOL1 CNAs were recurrent in cancer cell lines from CellMiner and Cancer Cell Line Encyclopedia (CCLE) databases (N=1087 cell lines) ( $\geq 10 \%$ of frequency). Indeed, in silico analysis revealed that thirty-one genes were covered by CNAs in most cancer cell lines (Table S2). In addition, by performing Ingenuity Pathway Analysis (IPA), it was revealed a total of 240 cancer-related genes, 
15 of them exclusively related with brain cancer (Table S3). Also, we analyzed whether CNAs detected in AHOL1 were frequently found across primary GBM tumors from TCGA database. Interestingly, the vast majority of genes covered by CNAs were commonly altered across several primary GBM tumors.

We also conducted an analysis to detect the main altered pathways affected by CNAs in the AHOL1 genome. Amplifications affected 60 pathways, such as putrescine degradation III, melatonin degradation II and leucine degradation pathways, while losses have no impact in any pathway (Table S4).

\section{AHOL1 is genomically similar to other human GBM cell lines}

Considering that the AHOL1 cell line was established from a GBM patient, we expected it to share common CNAs with commercial GBM cell lines (U87MG, U343 and 1321N1). As shown in Figure 2, our results indicate the existence of a common genomic signature between AHOL1 and commercial GBM cell lines (1321N1, U343 and U87), thus confirming its GBM identity.

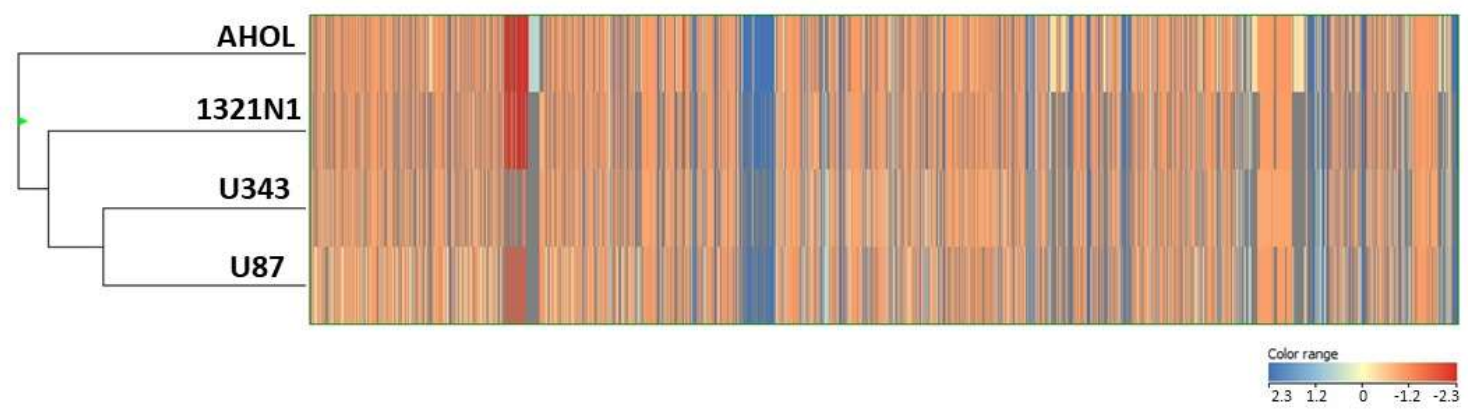

Figure 2. Heatmap of all CNAs present in each cell line (AHOL1, 1321N1, U343 and U87).

\section{Drugs targeting CNAs}

Potential drugs targeting CNAs were investigated using the DGIdb database. Nine druggable genes were identified, including HCRTR2 (hypocretin receptor 2), ETV1 (ETS variant 1), PTPRD (protein tyrosine phosphatase, receptor type D), PRKX (protein kinase X-linked), STS (steroid sulfatase), RPS6KA6 (ribosomal protein S6 kinase A6), ZFY (zinc finger protein Y-linked), USP9Y (ubiquitin specific peptidase 9 Y-linked) and KDM5D (lysine demethylase 5D) (Table 2). 
Table 2. Druggable genes of AHOL1 cell line. Information of each gene regarding their chromosomal location, cytoband, size $(\mathrm{kb})$, type of alteration found (Gain or Loss), drugs and the type of interaction of each drug is provided below.

\begin{tabular}{|c|c|c|c|c|c|c|}
\hline Chromosome & Cytoband & Size (Kb) & Variant type & Gene & Drug & Interaction Type \\
\hline 6 & $\mathrm{p} 12.1$ & 1,752 & Gain & HCRTR2 & $\begin{array}{c}\text { Suvorexant } \\
\text { SB-649868 } \\
\text { Lemborexant } \\
\text { Almorexant }\end{array}$ & $\begin{array}{c}\text { Antagonist } \\
\text { Antagonist } \\
\text { Antagonist } \\
\mathrm{n} / \mathrm{a}\end{array}$ \\
\hline 7 & $\mathrm{p} 21.3-\mathrm{p} 21.2$ & 3,393 & Gain & ETVI & Trametinib & $\mathrm{n} / \mathrm{a}$ \\
\hline 10 & $\mathrm{q} 21.1$ & 3,864 & Gain & PTPRD & $\begin{array}{l}\text { Cucurbitacin } \\
\text { Teprotumumab } \\
\text { Cixutumumab }\end{array}$ & $\begin{array}{l}\mathrm{n} / \mathrm{a} \\
\mathrm{n} / \mathrm{a} \\
\mathrm{n} / \mathrm{a}\end{array}$ \\
\hline $\mathbf{x}$ & p22.33 - p11.1 & 55,799 & Gain & PRKX & $\begin{array}{c}\text { GSK-690693 } \\
\text { Estrone } \\
\text { Danazol } \\
\text { Triptorelin } \\
\text { Penicillamine } \\
\text { Progesterone } \\
\text { STS }\end{array}$ & $\begin{array}{l}\text { Inhibitor } \\
\text { n/a } \\
\mathrm{n} / \mathrm{a} \\
\mathrm{n} / \mathrm{a} \\
\mathrm{n} / \mathrm{a} \\
\mathrm{n} / \mathrm{a} \\
\text { Inhibitor }\end{array}$ \\
\hline $\mathbf{x}$ & $\mathrm{q} 21.1-\mathrm{q} 21.33$ & 13,545 & Gain & RPS6KA6 & $\begin{array}{c}\text { AT-9283 } \\
\text { Chembl573107 }\end{array}$ & $\begin{array}{l}\text { Inhibitor } \\
\text { Inhibitor }\end{array}$ \\
\hline $\mathbf{Y}$ & $\mathrm{p} 11.31-\mathrm{p} 11.2$ & 7,119 & Loss & $Z F Y$ & Chembl383208 & $\mathrm{n} / \mathrm{a}$ \\
\hline $\mathbf{Y}$ & $\mathrm{q} 11.21$ - q12 & 45,327 & Loss & $\begin{array}{c}U S P 9 Y \\
K D M 5 D\end{array}$ & $\begin{array}{l}\text { Testosterone } \\
\text { Ascorbate }\end{array}$ & $\begin{array}{l}\mathrm{n} / \mathrm{a} \\
\mathrm{n} / \mathrm{a}\end{array}$ \\
\hline
\end{tabular}

\section{Transcriptome characterization of AHOL1 cell line}

In total, we identified 1,837 differentially expressed genes (DEGs). Among these, 713 genes were up-regulated, whereas 1,124 genes were down-regulated (FC $\geq 2$ and $\mathrm{p}<0.05$ ) (Table 3). A full list of differentially expressed genes and their corresponding fold changes in expression and $\mathrm{p}$ values is provided in Table S5. Ret Finger Protein-like 4A-like 1 (RFPL4AL1) was the most up-regulated (FC: 55.87), and lincRNA lnc-CHIC1-2:1 the most down-regulated mRNA (FC: -65.82) (Table 3).

Table 3. Characteristics of the top 20 differentially expressed mRNAs in AHOL1 cell line sorted by fold change (Fold change $\geq 2$ and $\mathrm{p}<0.05$ ). 


\begin{tabular}{|c|c|c|c|c|}
\hline & Gene symbol & Chromosome & Description & Fold-Change \\
\hline \multirow{7}{*}{ 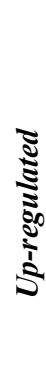 } & RFPL4AL1 & chr19 & Ret Finger Protein-like 4 A-like 1 & 55.87 \\
\hline & $\operatorname{lnc}-W D R 5-2$ & chr9 & lincRNA & 27.04 \\
\hline & ERICH1-AS1 & chr8 & lncRNA & 26.70 \\
\hline & LRRN4 & $\operatorname{chr} 7$ & Leucine Rich Repeat Neuronal 4 & 21.44 \\
\hline & CMTR1 & chr6 & Cap Methyltransferase 1 & 21.38 \\
\hline & $X L O C \_12 \_012743$ & $\operatorname{chr} 6$ & $\operatorname{lncRNA}$ & 11.53 \\
\hline & LINC01297 & chr14 & lincRNA & 10.86 \\
\hline \multirow{17}{*}{ 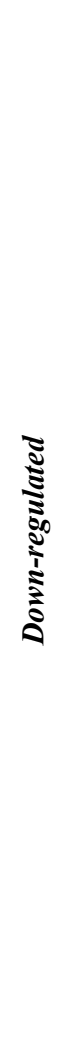 } & $K D M 4 E$ & $\operatorname{chr} 11$ & Lysine demethylase $4 E$ & 9.08 \\
\hline & $\operatorname{lnc}-R B P J-1: 1$ & $\operatorname{chr} 4$ & lincRNA & 8.59 \\
\hline & $\ln c-F B X O 25-5: 4$ & chr8 & lincRNA & 6.21 \\
\hline & $\operatorname{lnc}-\mathrm{CHIC1}-2: 1$ & $\operatorname{chr} \mathrm{X}$ & lincRNA & -65.82 \\
\hline & SHANK3 & $\operatorname{chr} 22$ & $\begin{array}{c}\text { SH3 and multiple ankyrin repeat } \\
\text { domains } 3\end{array}$ & -36.71 \\
\hline & SNORD114-3 & $\operatorname{chr} 14$ & Small nucleolar RNA, C/D box 114- & -18.68 \\
\hline & & & 3 & \\
\hline & LOC403323 & $\operatorname{chr} 9$ & Uncharacterized LOC403323 & -12.19 \\
\hline & ZFP57 & chr6 & ZFP57 zinc finger protein & -10.78 \\
\hline & CYP11A1 & $\operatorname{chr} 15$ & Cytochrome P450 family 11 & -9.88 \\
\hline & & & subfamily A member 1 & \\
\hline & $D S P$ & chr6 & Desmoplakin & -9.16 \\
\hline & PLVAP & chr19 & Plasmalemma vesicle associated & -8.89 \\
\hline & & & protein & \\
\hline & $C 4 B P A$ & $\operatorname{chr} 1$ & Complement component 4 binding & -8.72 \\
\hline & & & protein alpha & \\
\hline & $\operatorname{lnc}-Z N F 100-2$ & $\operatorname{chr} 19$ & $\operatorname{lncRNA}$ & -7.92 \\
\hline
\end{tabular}

To better understand the biological processes associated with DEGs, Gene Ontology (GO) analysis was conducted. The majority of DEGs was distributed into four GO categories: biological process, molecular function, cellular component and protein class (Figure 3). A full list of GO terms is provided in Table S6.

In the biological process category, the most enriched terms were related to biological regulation and metabolic process (Figure $3 \mathrm{~A}$ ). Binding and catalytic activity mostly accounted for terms related to the molecular function category (Figure 3B). Within the cellular component category, the GO term with the highest level of significance was cell, followed by membrane and organelle (Figure 3C). Finally, in the protein class category, the terms hydrolase and transcription factor exhibited the highest significance (Figure 3D). 


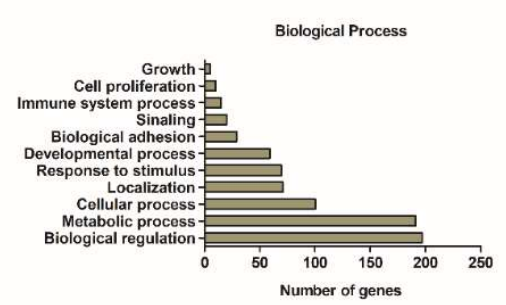

c)

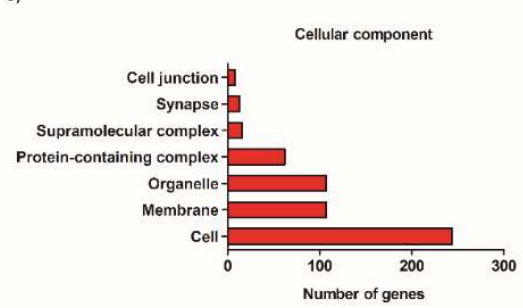

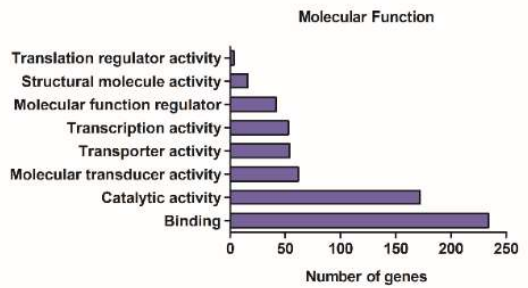

D)

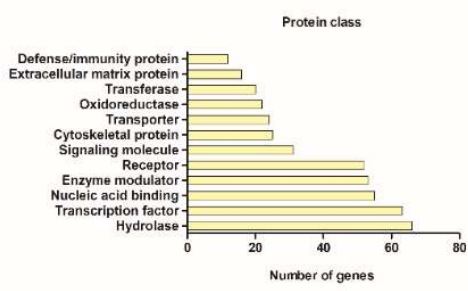

Figure 3. Gene Ontology (GO) functional annotations for DEGs of AHOL1 cell line. Bar graphs show four GO categories: (A) Biological processes, (B) Molecular functions, (C) Cellular components and (D) Protein classes. The X-axis represents the number of DEGs and the Y-axis shows the GO terms of each category (Fold change $\geq 2$ and $\mathrm{p}<0.05)$.

Pathway analysis was performed to investigate the biological significance of these DEGs. Thirteen pathways were significantly affected in the AHOL1 cell line, such as mevalonate, IL-1, glycogenolysis and mRNA capping pathways in cancer (Table 4).

Table 4. Pathway analysis of DEGs from AHOL1 cell line. Pathways were selected according to the $\mathrm{P}$ value (Fold change $\geq 2$ and $\mathrm{p}<0.05$ ).

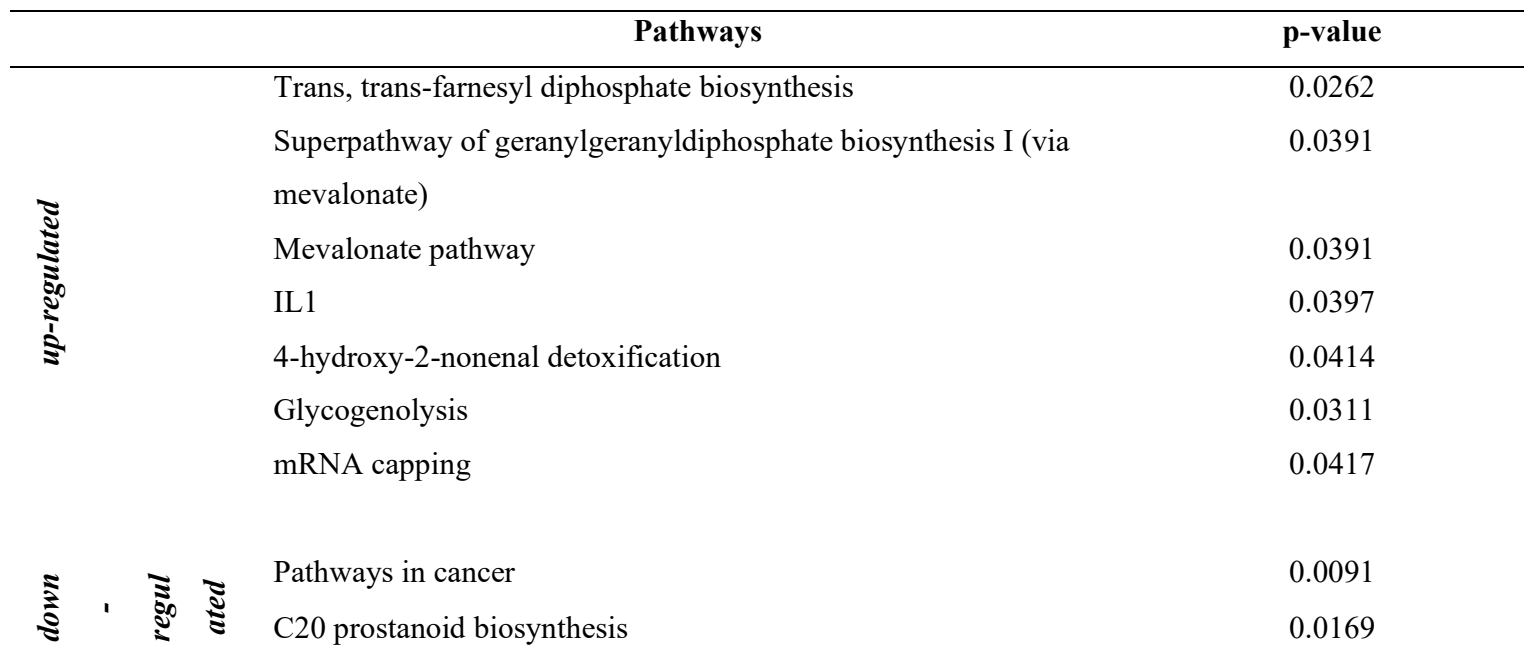




\section{AHOL1 cell line shares several DEGs with other commercial GBM cell lines}

To determine the number of genes shared between AHOL1 and the commercial GBM cell lines, Venn diagrams were created. Our results showed that AHOL1 shared several transcripts with the commercial GBM cell lines.

The analysis of transcriptomes highlighted that AHOL1 cell line has several changes common to the different GBM commercial cell lines. All cell lines had shared 756 up-regulated and 281 down-regulated genes (Figure 4).

A)

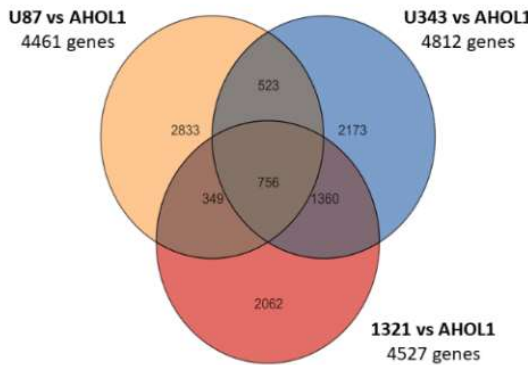

B)

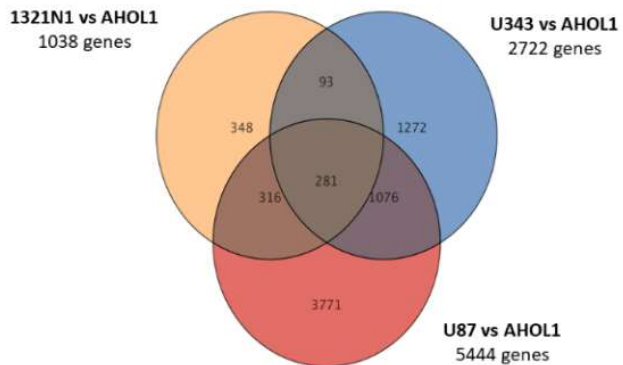

Figure 4. Venn diagram showing the number of genes up-regulated (a) and downregulated (b) in all GBM cell lines.

\section{Integrative Analysis of CNA and Gene Expression Profiling}

To explore and compare how CNAs affect AHOL1 transcriptional program, we performed an integrative analysis of CNAs with DEGs. Most of DEGs showed no positive correlation with CNAs. Only fifty-six genes displayed significant CNA-DEGs correlation in AHOL1 cell line. A full list of these overlapping genes is found in Table S7. Fourteen genes showed a positive association, while 42 genes presented an inverse association (Table 5).

Table 5. Overlapping genes identified after integration of CNAs and gene expression data of AHOL1 cell line.

\begin{tabular}{ccc}
\hline CNA & Gene expression & Overlapping genes \\
\hline Gain & Up-regulated & 13 \\
Gain & Down-regulated & 32
\end{tabular}


Loss Up-regulated 11

Loss Down-regulated 1

$\begin{array}{ll}\text { Total } & 57\end{array}$

To further understand the biological function of these 57 overlapping genes, they were submitted to functional annotation and classification analysis. Most of these genes were enriched for metabolic processes, biological regulation and cellular processes in the biological category (Figure 5A). For the molecular function category, the GO terms with the highest levels were catalytic activity, binding and transcription activity (Figure 5B). Within the cellular component category, cell was the highest term, followed by membrane and organelle terms (Figure 5C). Of note, in the protein class category, the terms nucleic acid binding and transcription factor exhibited the highest frequencies (Figure 5D).

Next, we performed separately GO functional annotation of each group shown in Table 7. As shown in Table S8, most genes covered by gains whose expression was up-regulated mainly affected the nucleus (Cellular Component), provoking changes in the DNA-binding transcription factor (TF) activity (Molecular Function) of the helixturn-helix and zinc finger TFs (Protein Class), which consequently had an effect on the cell development and cell differentiation (Biological process). 
Genes covered by gains and whose expression was down-regulated mostly affected the membranes (Cellular Component), especially disturbing the hydrolase activity (Molecular Function), modifying the cell communication, signal transduction, cellular response to stimulus and cellular metabolic process (Biological Process).

A)

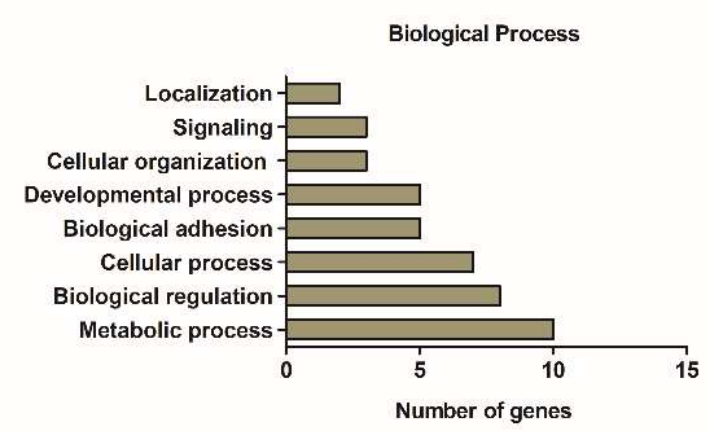

C)

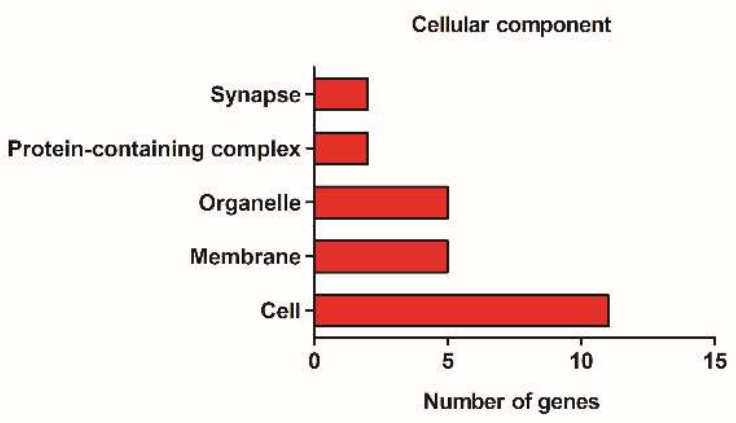

B)

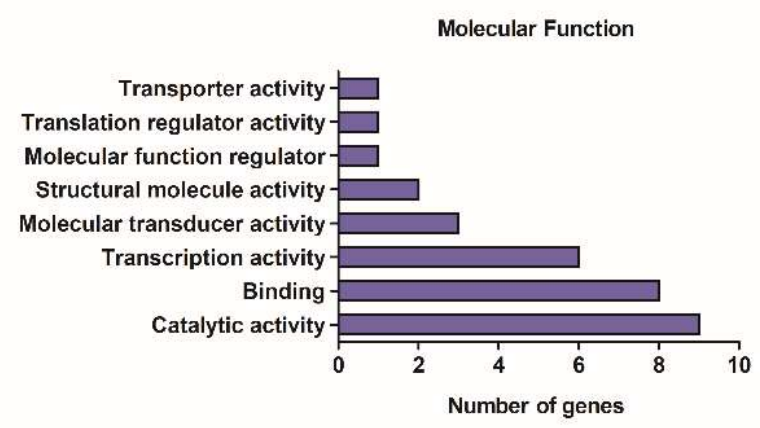

D)

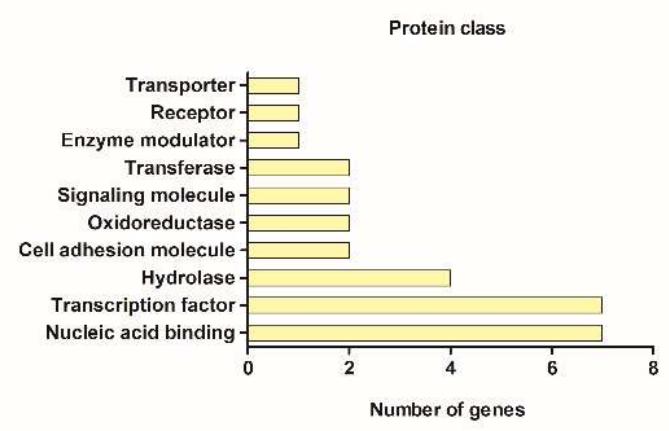

Furthermore, genes covered by losses and whose expression was up-regulated essentially affected the cytoplasm (Cellular Component), altering the RNA binding (Molecular Function) of the ribosomal proteins and translation factors (Protein Class), influencing the translational elongation and termination (Biological Process). Finally, PCDH11Y loss and down-regulation affected plasma membrane, by altering the cell adhesion and inducing changes in the calcium ion binding (Table S8).

Figure 5. Functional classification of integrated DEGs-CNAs data from AHOL1 cell line using Gene ontology (GO) analysis. Bar graphs show four independent GO information categories: (A) Biological processes, (B) Molecular functions, (C) Cellular components and (D) Protein classes. The Y-axis represents the number of genes of integrated DEGs-CNAs data and the X-axis shows the GO terms for each category $(\mathrm{p}<0.05)$. 
We also conducted a global analysis with all 57 genes from the DEGs-CNAs dataset, in order to detect the main altered pathways from AHOL1. Signaling pathways via Receptor-type tyrosine protein phosphatases, Cadherin, Wnt, FGFR1 and Akt, as well as metabolism of proteins were statistically significant.

\section{Gene expression Validation of the Microarray Results}

To validate the DEGs-CNAs dataset generated by microarray, we selected four genes related to cancer. Three of them (ANOS1, ETV1 and XPNPEP2) were upregulated via copy number gain and one gene $(P C D H 11 Y)$ was down-regulated via copy number loss. Transcription levels of selected genes are shown in Figure 6.

Gene expression showed that ANOS1, ETV1 and XPNPEP2 were up-regulated in AHOL1 relative to normal brain tissue fragments (2-fold; $>4$ fold; 2.7-fold respectively), which is in line with the microarray data (Figure 6 and Table S5). Of note, $P C D H 11 Y$ was 2.3-fold down-regulated in AHOL1 relative to normal brain tissues, in

A)

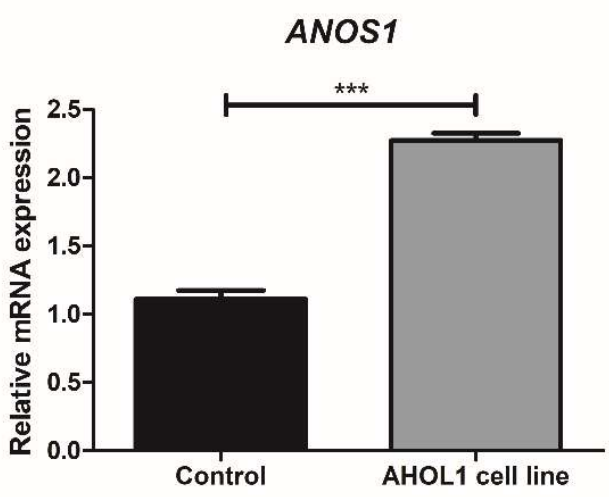

C)

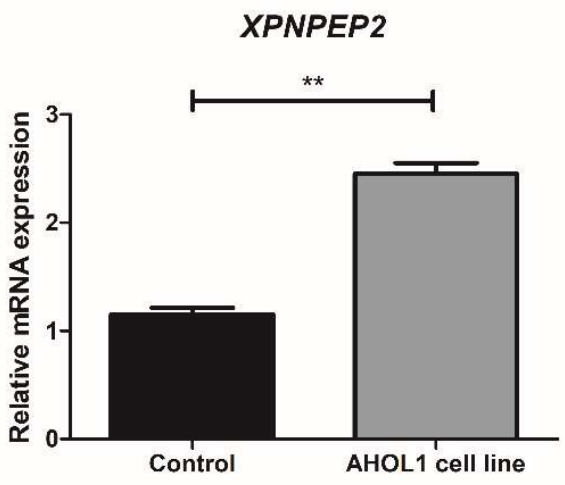

B)

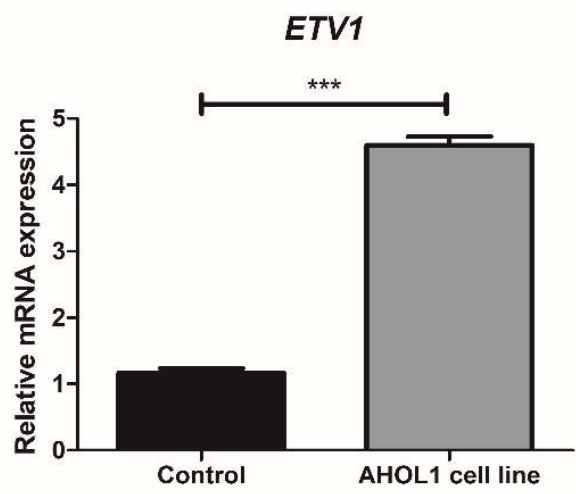

D)

PCDH11Y

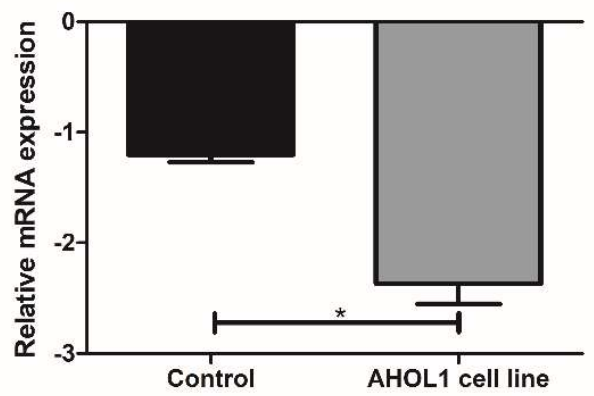

agreement with the microarray data (Figure 6D; Table S5). 
Figure 6. Validation of the microarray data by qRT-PCR. qRT-PCR was performed for ANOS1 (A), ETV1 (B), XPNPEP2 (C) and PCDH11Y (D) genes. Data were expressed as fold-change in mRNA expression and compared with a tissue fragment from normal brain as a control. Each bar represents mean $\pm \mathrm{SD}$ values for each gene with three technical replicates. Statistical significance was determined using student's t test and denoted by asterisks: $*$ indicates $\mathrm{p}<0.05$; ** indicates $\mathrm{p}<0.01$; *** indicates $\mathrm{p}<0.001$.

\section{DISCUSSION}

Recent data provided by The Cancer Genome Atlas (TCGA) consortium have shown great genetic and epigenetic diversity among GBM tumors [5, 23-28]. The elucidation of the biological mechanisms and the complexity behind this diversity is a central challenge for achieving precision medicine in GBM subtypes. For this reason, the availability of a large number of molecularly well-characterized GBM cell lines may have a high impact on understanding the complex biology of this tumor, thus contributing to identification of new therapeutic targets.

As an attempt to better understand the complexity of the GBM biology and the phenomena that pervade the aspects of its intricate mechanisms, we provide the first comprehensive molecular profile of the new human glioblastoma cell line AHOL1. This cell line clearly exhibited recurrent CNAs consistent with those observed in primary GBM tumors from TCGA database, CellMiner and Cancer Cell Line Encyclopedia, as well as the commercial GBM cell lines (1321N1, U343 and U87) used in this study and other reports [57-67]. Among these, the most prominent CNAs were documented at X (gain of entire chromosome) and Y-chromosomes (loss of entire chromosome), in line with previous cytogenetics and molecular reports for GBM tumors [65, 68-70]. Although many functional aspects of CNAs at chr X and chr Y have not yet been extensively studied in cancer, a preliminary study suggested that high expression of SPIN4 and ASB12 was correlated with amplification at Xq11 in GBM [71], thus affecting several important biological processes, such as mitosis, Wnt signaling pathway, H3K4me3 and post-translational protein modifications [72]. Recent reports also support that the $\mathrm{X}$ chromosome gain plays a prominent role in the neoplastic 
transformation of breast cancer [73-78], chronic neutrophilic leukemia [79], nonHodgkin lymphoma [80, 81], papillary renal cell carcinoma [82], renal cell carcinoma [83] and prostate cancer [84].

Massive amounts of cancer genomics data generated from next-generation sequencing have motivated investigators to develop novel computational approaches for the identification of new druggable genes, which can be used as therapeutic targets in the precision cancer medicine [85]. Our AHOL1 genomic data showed that nine genes (HCRTR2; ETV1; PTPRD; PRKX; STS; RPS6KA6; ZFY; USP9Y and KDM5D) are known as potential druggable anticancer targets, and some of them could be druggable vulnerabilities in some subtypes of GBM [86]. Together, these studies have highlighted the great potential of AHOL1 cell line for in vitro studies.

The association between CNAs and gene expression profiling suggested that the identified CNAs could contribute to the expression of some but not all genes. In some cases, expression changes were inconsistent with the CNAs. This might be influenced by other factors that contribute to gene expression variation, such as epigenetics changes, non-coding RNA regulation, gene mutation and altered expression of TFs [87]. This apparent discrepancy between copy number status and gene expression has also been observed in other cancers [88-93].

In this study, pathway enrichment of CNA-driven DEGs indicated significant changes in six pathways, where the majority of genes were prominently involved in the signaling by tyrosine phosphorylation. Tyrosine phosphorylation plays an important role in regulating cellular function and is a central feature in signaling cascades involved in oncogenesis [94, 95]. This process is coordinately controlled by protein tyrosine phosphatase (PTPs) and protein tyrosine kinases (PTKs) [95], which are altered in a variety of human cancers [96, 97], including GBMs [98-106]. Among the tyrosine phosphatases, the tumor suppressor PTPRD is one of those often inactivated by deletion ( $>50 \%$ of cases), whose loss of expression promotes gliomagenesis through aberrant STAT3 activation [107] and is related with poor prognosis in GBM patients [98]. Our observations, therefore, suggested that this gene was amplified and down-regulated in AHOL1. Perhaps, this gene might be epigenetically silenced in AHOL1, once GBMs that do not harbor loss of PTPRD have this gene inactivated by its promoter hypermethylation $[98,108]$.

Assuming that CNA-DEG integrated data have been shown to be an efficient approach to identify genes covered by altered CNAs that directly change their 
expression levels, not all genes of our integrated dataset were cancer-related [89]. In order to explore only genes related to cancer, we selected four genes, including three positively correlated genes with gain (ANOS1, ETV1 and XPNPEP2) and one negatively correlated gene with loss $(P C D H 11 Y)$.

$A N O S 1$, also known as $K A L 1$, encodes anosmin-1, an extracellular matrix (ECM)-associated protein that plays essential roles in neural cell adhesion and axonal migration. The upregulation of this gene in the AHOL1 cell line is consistent with the results from Choy et al. [109] for GBM and low-grade astrocytic tumors, as they found that anosmin-1 enhanced cell motility and proliferation in GBM cell lines. The overexpression of ANOS1 is also related to development and metastasis of colorectal cancer and its expression is closely related to the overall survival rate of patients $[110$, $111]$.

We also identified that the up-regulation of ETV1, an important oncogene involved in transcriptional regulatory processes in GBMs [112], was due to a chromosome 7 gain in AHOL1 genome. It has been shown that chromosome 7 gain is a key event in G-CIMP-negative GBMs [23, 113], and high expression of ETV1 may be a potential downstream effector of chromosome 7 gain [112]. Previous study also revealed that ETV1 is fused with $D G K B$ and may act as oncogenic drivers in pediatric high-grade gliomas [114].

XPNPEP2 is a membrane-bound aminopeptidase P member of the 'pita bread fold' family, which catalyzes the removal of the penultimate prolyl residue from Ntermini of peptides. Although it is known that this aminopeptidase activates growth factors, hormones, coagulants, toxins, cytokines and neurotransmitters [115], the role of $X P N P E P 2$ in cancer is still unknown. It is known that XPNPEP2 is overexpressed in cervical cancer, promoting cell invasion and migration without affecting cell proliferation and apoptosis [116]. Our gene expression results corroborate these findings and point out that XPNPEP2 can be up-regulated in GBM.

Protocadherins constitute the largest subfamily of cadherins in the genome. Protocadherins genes are predominantly expressed in the nervous system, acting in crucial functions associated with formation, maintenance, and integrity of the neural circuit $[117,118]$. Recently, they have been in the spotlight for their roles in cancer [119]. Protocadherin-11Y (also named as PCDH11Y) is a proto-oncogene candidate exclusively found in man [120] and its transcription occurs mainly in the brain [118]. This gene is up-regulated in prostate carcinoma [121], inducing neuroendocrine 
transdifferentiation through activation of the wnt signaling [122]. To the best of our knowledge, this is the first study showing that PCDH11Y is overexpressed in GBM, contradicting the results found elsewhere [121].

In summary, we described for the first time the genome and transcriptome of the new human cell line AHOL1, established from a GBM patient. Here, we revealed that this cell line harbors a genomic alteration spectrum similar to what is observed in commercial GBM cell lines (U87MG, U343 and 1321N1) and GBMs from the TCGA database, and some of these CNAs can be targeted by drugs, suggesting that this new cell line is a suitable model system for understanding the molecular characteristics of human GBM tumorigenesis.

\section{Author Contributions}

Conceptualization, W.A.S.F. and E.H.C.O.; methodology, W.A.S.F. and C.K.N.A.; software, W.A.S.F., R.A.R.V. and F.A.M.; validation, W.A.S.F.; formal analysis, W.A.S.F., R.R.B., T.S.M., E.H.C.O.; investigation, W.A.S.F.; resources, W.A.S.F., R.R.B. and E.H.C.O.; writing-original draft preparation, W.A.S.F.; writing - review and editing, W.A.S.F., T.S.M. and E.H.C.O.; visualization, W.A.S.F. and E.H.C.O.; supervision, E.H.C.O.

\section{Funding}

This research was funded by Conselho Nacional de Desenvolvimento Científico e Tecnológico (CNPq) (Grant Number: 455078/2014-9) and Evandro Chagas Institute.

\section{Acknowledgments}

Authors are grateful to Instituto Evandro Chagas (Ananindeua, PA, Brazil), Pró-Reitoria de Pesquisa e Pós-Graduação (PROPESP/UFPA, Belém, PA) and CNPq for financial and technical support; to the Hospital Ophir Loyola (Belém, PA) and the patient's family for the consent to participate in this project; to Dr. Rommel Rodriguez Burbano for providing the AHOL1 cell line used in this study; to Coordenação de Aperfeiçoamento de Pessoal de Nível Superior (CAPES) for Wallax Augusto Silva Ferreira's Phd fellowship. 


\section{Conflict of interest}

The authors declare that they have no conflict of interest.

\section{Abbreviations}

AHOL1: Astrocytoma Ophir Loyola Hospital 1

CNAs: Copy number alterations

CNS: Central Nervous System

DEGs: Differentially expressed genes

GBM: Glioblastoma

IDH: isocitrate dehydrogenase

SVZ: subventricular zone

WHO: World Health Organization 


\section{References}

1. Kwan, K.; Schneider, J. R.; Patel, N. V.; Boockvar, J. A., Tracing the Origin of Glioblastoma: Subventricular Zone Neural Stem Cells. Neurosurgery 2019, 84, (1), E15E16.

2. Lee, J. H.; Lee, J. E.; Kahng, J. Y.; Kim, S. H.; Park, J. S.; Yoon, S. J.; Um, J. Y.; Kim, W. K.; Lee, J. K.; Park, J.; Kim, E. H.; Lee, J. H.; Lee, J. H.; Chung, W. S.; Ju, Y. S.; Park, S. H.; Chang, J. H.; Kang, S. G.; Lee, J. H., Human glioblastoma arises from subventricular zone cells with low-level driver mutations. Nature 2018, 560, (7717), 243-247.

3. Ostrom, Q. T.; Gittleman, H.; Truitt, G.; Boscia, A.; Kruchko, C.; Barnholtz-Sloan, J. S., CBTRUS Statistical Report: Primary Brain and Other Central Nervous System Tumors Diagnosed in the United States in 2011-2015. Neuro-oncology 2018, 20, (suppl_4), iv1iv86.

4. Tamimi, A. F.; Juweid, M., Epidemiology and Outcome of Glioblastoma. In Glioblastoma, De Vleeschouwer, S., Ed. Brisbane (AU), 2017.

5. Louis, D. N.; Perry, A.; Reifenberger, G.; von Deimling, A.; Figarella-Branger, D.; Cavenee, W. K.; Ohgaki, H.; Wiestler, O. D.; Kleihues, P.; Ellison, D. W., The 2016 World Health Organization Classification of Tumors of the Central Nervous System: a summary. Acta neuropathologica 2016, 131, (6), 803-20.

6. Ohgaki, H.; Burger, P.; Kleihues, P., Definition of primary and secondary glioblastoma-response. Clinical cancer research : an official journal of the American Association for Cancer Research 2014, 20, (7), 2013.

7. Wesseling, P.; Capper, D., WHO 2016 Classification of gliomas. Neuropathology and applied neurobiology 2018, 44, (2), 139-150.

8. Ohgaki, H.; Kleihues, P., The definition of primary and secondary glioblastoma. Clinical cancer research : an official journal of the American Association for Cancer Research 2013, 19, (4), 764-72.

9. Yin, A.-a.; Zhang, L.-h.; Cheng, J.-X.; Dong, Y.; Liu, B.-I.; Han, N.; Zhang, X., Radiotherapy plus concurrent or sequential temozolomide for glioblastoma in the elderly: a metaanalysis. PloS one $\mathbf{2 0 1 3}, \mathbf{8},(9)$, e74242.

10. Stupp, R.; Taillibert, S.; Kanner, A. A.; Kesari, S.; Steinberg, D. M.; Toms, S. A.; Taylor, L. P.; Lieberman, F.; Silvani, A.; Fink, K. L., Maintenance therapy with tumor-treating fields plus temozolomide vs temozolomide alone for glioblastoma: a randomized clinical trial. Jama 2015, 314, (23), 2535-2543.

11. Perry, J. R.; Laperriere, N.; O'callaghan, C. J.; Brandes, A. A.; Menten, J.; Phillips, C.; Fay, M.; Nishikawa, R.; Cairncross, J. G.; Roa, W., Short-course radiation plus temozolomide in elderly patients with glioblastoma. New England Journal of Medicine 2017, 376, (11), 1027-1037.

12. Geraldo, L. H. M.; Garcia, C.; da Fonseca, A. C. C.; Dubois, L. G. F.; Matias, D.; de Camargo Magalhães, E. S.; do Amaral, R. F.; da Rosa, B. G.; Grimaldi, I.; Leser, F. S., Glioblastoma Therapy in the Age of Molecular Medicine. Trends in cancer 2018.

13. Nam, J. Y.; de Groot, J. F., Treatment of Glioblastoma. Journal of oncology practice 2017, 13, (10), 629-638.

14. Ferreira, W. A.; Pinheiro Ddo, R.; Costa Junior, C. A.; Rodrigues-Antunes, S.; Araujo, M. D.; Leao Barros, M. B.; Teixeira, A. C.; Faro, T. A.; Burbano, R. R.; Oliveira, E. H.; Harada, M. L.; Borges Bdo, N., An update on the epigenetics of glioblastomas. Epigenomics 2016, 8, (9), 1289-305.

15. Hanif, F.; Muzaffar, K.; Perveen, K.; Malhi, S. M.; Simjee Sh, U., Glioblastoma Multiforme: A Review of its Epidemiology and Pathogenesis through Clinical Presentation and Treatment. Asian Pacific journal of cancer prevention : APJCP 2017, $18,(1), 3-9$. 
16. Baskaran, S.; Mayrhofer, M.; Kultima, H. G.; Bergström, T.; Elfineh, L.; Cavelier, L.; Isaksson, A.; Nelander, S., Primary glioblastoma cells for precision medicine: a quantitative portrait of genomic (in) stability during the first 30 passages. Neurooncology 2018, 20, (8), 1080-1091.

17. Pollard, S. M.; Yoshikawa, K.; Clarke, I. D.; Danovi, D.; Stricker, S.; Russell, R.; Bayani, J.; Head, R.; Lee, M.; Bernstein, M., Glioma stem cell lines expanded in adherent culture have tumor-specific phenotypes and are suitable for chemical and genetic screens. Cell stem cell 2009, 4, (6), 568-580.

18. Rutka, J.; Giblin, J.; Dougherty, D.; Liu, H.; McCulloch, J.; Bell, C.; Stern, R.; Wilson, C.; Rosenblum, M., Establishment and characterization of five cell lines derived from human malignant gliomas. Acta neuropathologica 1987, 75, (1), 92-103.

19. Xie, Y.; Bergström, T.; Jiang, Y.; Johansson, P.; Marinescu, V. D.; Lindberg, N.; Segerman, A.; Wicher, G.; Niklasson, M.; Baskaran, S., The human glioblastoma cell culture resource: validated cell models representing all molecular subtypes. EBioMedicine 2015, 2, (10), 1351-1363.

20. Kiseleva, L.; Kartashev, A.; Vartanyan, N.; Pinevich, A.; Filatov, M.; Samoilovich, M., Characterization of new human glioblastoma cell lines. Cell and Tissue Biology 2018, 12, (1), 1-6.

21. Xie, Y.; Bergstrom, T.; Jiang, Y.; Johansson, P.; Marinescu, V. D.; Lindberg, N.; Segerman, A.; Wicher, G.; Niklasson, M.; Baskaran, S.; Sreedharan, S.; Everlien, I.; Kastemar, M.; Hermansson, A.; Elfineh, L.; Libard, S.; Holland, E. C.; Hesselager, G.; Alafuzoff, I.; Westermark, B.; Nelander, S.; Forsberg-Nilsson, K.; Uhrbom, L., The Human Glioblastoma Cell Culture Resource: Validated Cell Models Representing All Molecular Subtypes. EBioMedicine 2015, 2, (10), 1351-63.

22. Korshunov, A.; Casalini, B.; Chavez, L.; Hielscher, T.; Sill, M.; Ryzhova, M.; Sharma, T.; Schrimpf, D.; Stichel, D.; Capper, D.; Reuss, D. E.; Sturm, D.; Absalyamova, O.; Golanov, A.; Lambo, S.; Bewerunge-Hudler, M.; Lichter, P.; Herold-Mende, C.; Wick, W.; Pfister, S. M.; Kool, M.; Jones, D. T. W.; von Deimling, A.; Sahm, F., Integrated molecular characterization of IDH-mutant glioblastomas. Neuropathology and applied neurobiology 2018.

23. Noushmehr, H.; Weisenberger, D. J.; Diefes, K.; Phillips, H. S.; Pujara, K.; Berman, B. P.; Pan, F.; Pelloski, C. E.; Sulman, E. P.; Bhat, K. P.; Verhaak, R. G.; Hoadley, K. A.; Hayes, D. N.; Perou, C. M.; Schmidt, H. K.; Ding, L.; Wilson, R. K.; Van Den Berg, D.; Shen, H.; Bengtsson, H.; Neuvial, P.; Cope, L. M.; Buckley, J.; Herman, J. G.; Baylin, S. B.; Laird, P. W.; Aldape, K.; Cancer Genome Atlas Research, N., Identification of a CpG island methylator phenotype that defines a distinct subgroup of glioma. Cancer cell 2010, 17, (5), 510-22.

24. Kloosterhof, N. K.; de Rooi, J. J.; Kros, M.; Eilers, P. H.; Sillevis Smitt, P. A.; van den Bent, M. J.; French, P. J., Molecular subtypes of glioma identified by genome-wide methylation profiling. Genes, chromosomes \& cancer 2013, 52, (7), 665-74.

25. Phillips, H. S.; Kharbanda, S.; Chen, R.; Forrest, W. F.; Soriano, R. H.; Wu, T. D.; Misra, A.; Nigro, J. M.; Colman, H.; Soroceanu, L.; Williams, P. M.; Modrusan, Z.; Feuerstein, B. G.; Aldape, K., Molecular subclasses of high-grade glioma predict prognosis, delineate a pattern of disease progression, and resemble stages in neurogenesis. Cancer cell 2006, 9, (3), 157-73.

26. Li, A.; Walling, J.; Ahn, S.; Kotliarov, Y.; Su, Q.; Quezado, M.; Oberholtzer, J. C.; Park, J.; Zenklusen, J. C.; Fine, H. A., Unsupervised analysis of transcriptomic profiles reveals six glioma subtypes. Cancer research 2009, 69, (5), 2091-9.

27. Verhaak, R. G.; Hoadley, K. A.; Purdom, E.; Wang, V.; Qi, Y.; Wilkerson, M. D.; Miller, C. R.; Ding, L.; Golub, T.; Mesirov, J. P.; Alexe, G.; Lawrence, M.; O'Kelly, M.; Tamayo, P.; Weir, B. A.; Gabriel, S.; Winckler, W.; Gupta, S.; Jakkula, L.; Feiler, H. S.; Hodgson, J. G.; James, C. D.; Sarkaria, J. N.; Brennan, C.; Kahn, A.; Spellman, P. T.; Wilson, R. K.; Speed, 
T. P.; Gray, J. W.; Meyerson, M.; Getz, G.; Perou, C. M.; Hayes, D. N.; Cancer Genome Atlas Research, N., Integrated genomic analysis identifies clinically relevant subtypes of glioblastoma characterized by abnormalities in PDGFRA, IDH1, EGFR, and NF1. Cancer cell 2010, 17, (1), 98-110.

28. Brennan, C.; Momota, H.; Hambardzumyan, D.; Ozawa, T.; Tandon, A.; Pedraza, A.; Holland, E., Glioblastoma subclasses can be defined by activity among signal transduction pathways and associated genomic alterations. PloS one 2009, 4, (11), e7752.

29. Godlewski, J.; Ferrer-Luna, R.; Rooj, A. K.; Mineo, M.; Ricklefs, F.; Takeda, Y. S.; Nowicki, M. O.; Salinska, E.; Nakano, I.; Lee, H.; Weissleder, R.; Beroukhim, R.; Chiocca, E. A.; Bronisz, A., MicroRNA Signatures and Molecular Subtypes of Glioblastoma: The Role of Extracellular Transfer. Stem cell reports 2017, 8, (6), 1497-1505.

30. Pereira, E. L.; Lima, P. D.; Khayat, A. S.; Bahia, M. O.; Bezerra, F. S.; Andrade-Neto, M.; Montenegro, R. C.; Pessoa, C.; Costa-Lotufo, L. V.; Moraes, M. O.; Yoshioka, F. K.; Pinto, G. R.; Burbano, R. R., Inhibitory effect of pisosterol on human glioblastoma cell lines with C-MYC amplification. Journal of applied toxicology : JAT 2011, 31, (6), 554-60.

31. Pereira, E. L. R. Efeito do pisosterol em cultura de astrocitomas malignos. Universidade Federal do Pará, 2010.

32. Ponten, J.; Macintyre, E. H., Long term culture of normal and neoplastic human glia. Acta pathologica et microbiologica Scandinavica 1968, 74, (4), 465-86.

33. Jeannotte, R.; Lee, E.; Kong, N.; Ng, W.; Kelly, L.; Weimer, B., High-throughput analysis of foodborne bacterial genomic DNA using Agilent 2200 TapeStation and genomic DNA ScreenTape system. Agilent Technologies 2014.

34. Kong, N.; Ng, W.; Cai, L.; Leonardo, A.; Kelly, L.; Weimer, B., Integrating the DNA integrity number (DIN) to assess genomic DNA (gDNA) quality control using the Agilent 2200 TapeStation system. Agilent Technologies Application Note. doi 2014, 10.

35. Padmanaban, A.; Salowsky, R.; Cher, C., RNA quality control using the agilent 2200 TapeStation system-assessment of the RIN e quality metric. Agilent technologies application notes 2012.

36. Wolfe, D.; Dudek, S.; Ritchie, M. D.; Pendergrass, S. A., Visualizing genomic information across chromosomes with PhenoGram. BioData mining 2013, 6, (1), 18.

37. Reinhold, W. C.; Sunshine, M.; Liu, H.; Varma, S.; Kohn, K. W.; Morris, J.; Doroshow, J.; Pommier, Y., CellMiner: a web-based suite of genomic and pharmacologic tools to explore transcript and drug patterns in the $\mathrm{NCl}-60$ cell line set. Cancer research 2012, 72, (14), 3499-511.

38. Barretina, J.; Caponigro, G.; Stransky, N.; Venkatesan, K.; Margolin, A. A.; Kim, S.; Wilson, C. J.; Lehar, J.; Kryukov, G. V.; Sonkin, D.; Reddy, A.; Liu, M.; Murray, L.; Berger, M. F.; Monahan, J. E.; Morais, P.; Meltzer, J.; Korejwa, A.; Jane-Valbuena, J.; Mapa, F. A.; Thibault, J.; Bric-Furlong, E.; Raman, P.; Shipway, A.; Engels, I. H.; Cheng, J.; Yu, G. K.; Yu, J.; Aspesi, P., Jr.; de Silva, M.; Jagtap, K.; Jones, M. D.; Wang, L.; Hatton, C.; Palescandolo, E.; Gupta, S.; Mahan, S.; Sougnez, C.; Onofrio, R. C.; Liefeld, T.; MacConaill, L.; Winckler, W.; Reich, M.; Li, N.; Mesirov, J. P.; Gabriel, S. B.; Getz, G.; Ardlie, K.; Chan, V.; Myer, V. E.; Weber, B. L.; Porter, J.; Warmuth, M.; Finan, P.; Harris, J. L.; Meyerson, M.; Golub, T. R.; Morrissey, M. P.; Sellers, W. R.; Schlegel, R.; Garraway, L. A., The Cancer Cell Line Encyclopedia enables predictive modelling of anticancer drug sensitivity. Nature 2012, 483, (7391), 603-7.

39. Brennan, C. W.; Verhaak, R. G.; McKenna, A.; Campos, B.; Noushmehr, H.; Salama, S. R.; Zheng, S.; Chakravarty, D.; Sanborn, J. Z.; Berman, S. H.; Beroukhim, R.; Bernard, B.; Wu, C. J.; Genovese, G.; Shmulevich, I.; Barnholtz-Sloan, J.; Zou, L.; Vegesna, R.; Shukla, S. A.; Ciriello, G.; Yung, W. K.; Zhang, W.; Sougnez, C.; Mikkelsen, T.; Aldape, K.; Bigner, D. D.; Van Meir, E. G.; Prados, M.; Sloan, A.; Black, K. L.; Eschbacher, J.; Finocchiaro, G.; Friedman, W.; Andrews, D. W.; Guha, A.; lacocca, M.; O'Neill, B. P.; Foltz, G.; Myers, J.; 
Weisenberger, D. J.; Penny, R.; Kucherlapati, R.; Perou, C. M.; Hayes, D. N.; Gibbs, R.; Marra, M.; Mills, G. B.; Lander, E.; Spellman, P.; Wilson, R.; Sander, C.; Weinstein, J.; Meyerson, M.; Gabriel, S.; Laird, P. W.; Haussler, D.; Getz, G.; Chin, L.; Network, T. R., The somatic genomic landscape of glioblastoma. Cell 2013, 155, (2), 462-77.

40. Cancer Genome Atlas Research, N., Comprehensive genomic characterization defines human glioblastoma genes and core pathways. Nature 2008, 455, (7216), 1061-8.

41. Liu, J.; Lichtenberg, T.; Hoadley, K. A.; Poisson, L. M.; Lazar, A. J.; Cherniack, A. D.; Kovatich, A. J.; Benz, C. C.; Levine, D. A.; Lee, A. V.; Omberg, L.; Wolf, D. M.; Shriver, C. D.; Thorsson, V.; Cancer Genome Atlas Research, N.; Hu, H., An Integrated TCGA PanCancer Clinical Data Resource to Drive High-Quality Survival Outcome Analytics. Cell 2018, 173, (2), 400-416 e11.

42. Sanchez-Vega, F.; Mina, M.; Armenia, J.; Chatila, W. K.; Luna, A.; La, K. C.; Dimitriadoy, S.; Liu, D. L.; Kantheti, H. S.; Saghafinia, S.; Chakravarty, D.; Daian, F.; Gao, Q.; Bailey, M. H.; Liang, W. W.; Foltz, S. M.; Shmulevich, I.; Ding, L.; Heins, Z.; Ochoa, A.; Gross, B.; Gao, J.; Zhang, H.; Kundra, R.; Kandoth, C.; Bahceci, I.; Dervishi, L.; Dogrusoz, U.; Zhou, W.; Shen, H.; Laird, P. W.; Way, G. P.; Greene, C. S.; Liang, H.; Xiao, Y.; Wang, C.; lavarone, A.; Berger, A. H.; Bivona, T. G.; Lazar, A. J.; Hammer, G. D.; Giordano, T.; Kwong, L. N.; McArthur, G.; Huang, C.; Tward, A. D.; Frederick, M. J.; McCormick, F.; Meyerson, M.; Cancer Genome Atlas Research, N.; Van Allen, E. M.; Cherniack, A. D.; Ciriello, G.; Sander, C.; Schultz, N., Oncogenic Signaling Pathways in The Cancer Genome Atlas. Cell 2018, 173, (2), 321-337 e10.

43. Hoadley, K. A.; Yau, C.; Hinoue, T.; Wolf, D. M.; Lazar, A. J.; Drill, E.; Shen, R.; Taylor, A. M.; Cherniack, A. D.; Thorsson, V.; Akbani, R.; Bowlby, R.; Wong, C. K.; Wiznerowicz, M.; Sanchez-Vega, F.; Robertson, A. G.; Schneider, B. G.; Lawrence, M. S.; Noushmehr, H.; Malta, T. M.; Cancer Genome Atlas, N.; Stuart, J. M.; Benz, C. C.; Laird, P. W., Cell-ofOrigin Patterns Dominate the Molecular Classification of 10,000 Tumors from 33 Types of Cancer. Cell 2018, 173, (2), 291-304 e6.

44. Taylor, A. M.; Shih, J.; Ha, G.; Gao, G. F.; Zhang, X.; Berger, A. C.; Schumacher, S. E.; Wang, C.; Hu, H.; Liu, J.; Lazar, A. J.; Cancer Genome Atlas Research, N.; Cherniack, A. D.; Beroukhim, R.; Meyerson, M., Genomic and Functional Approaches to Understanding Cancer Aneuploidy. Cancer cell 2018, 33, (4), 676-689 e3.

45. Gao, Q.; Liang, W. W.; Foltz, S. M.; Mutharasu, G.; Jayasinghe, R. G.; Cao, S.; Liao, W. W.; Reynolds, S. M.; Wyczalkowski, M. A.; Yao, L.; Yu, L.; Sun, S. Q.; Fusion Analysis Working, G.; Cancer Genome Atlas Research, N.; Chen, K.; Lazar, A. J.; Fields, R. C.; Wendl, M. C.; Van Tine, B. A.; Vij, R.; Chen, F.; Nykter, M.; Shmulevich, I.; Ding, L., Driver Fusions and Their Implications in the Development and Treatment of Human Cancers. Cell Rep 2018, 23, (1), 227-238 e3.

46. Cerami, E.; Gao, J.; Dogrusoz, U.; Gross, B. E.; Sumer, S. O.; Aksoy, B. A.; Jacobsen, A.; Byrne, C. J.; Heuer, M. L.; Larsson, E.; Antipin, Y.; Reva, B.; Goldberg, A. P.; Sander, C.; Schultz, N., The cBio cancer genomics portal: an open platform for exploring multidimensional cancer genomics data. Cancer discovery 2012, 2, (5), 401-4.

47. Abbott, K. L.; Nyre, E. T.; Abrahante, J.; Ho, Y. Y.; Isaksson Vogel, R.; Starr, T. K., The Candidate Cancer Gene Database: a database of cancer driver genes from forward genetic screens in mice. Nucleic acids research 2015, 43, (Database issue), D844-8.

48. Liu, D.; Xu, X.; Wen, J.; Xie, L.; Zhang, J.; Shen, Y.; Jiang, G.; Chen, J.; Fan, M., Integrated Genome-Wide Analysis of Gene Expression and DNA Copy Number Variations Highlights Stem Cell-Related Pathways in Small Cell Esophageal Carcinoma. Stem cells international 2018, 2018, 3481783.

49. Wagner, A. H.; Coffman, A. C.; Ainscough, B. J.; Spies, N. C.; Skidmore, Z. L.; Campbell, K. M.; Krysiak, K.; Pan, D.; McMichael, J. F.; Eldred, J. M., DGIdb 2.0: mining clinically relevant drug-gene interactions. Nucleic acids research 2015, 44, (D1), D1036-D1044. 
50. Cotto, K. C.; Wagner, A. H.; Feng, Y. Y.; Kiwala, S.; Coffman, A. C.; Spies, G.; Wollam, A.; Spies, N. C.; Griffith, O. L.; Griffith, M., DGIdb 3.0: a redesign and expansion of the drug-gene interaction database. Nucleic acids research 2018, 46, (D1), D1068-D1073.

51. Zhu, F.; Shi, Z.; Qin, C.; Tao, L.; Liu, X.; Xu, F.; Zhang, L.; Song, Y.; Liu, X.; Zhang, J.; Han, B.; Zhang, P.; Chen, Y., Therapeutic target database update 2012: a resource for facilitating target-oriented drug discovery. Nucleic acids research 2012, 40, (Database issue), D1128-36.

52. Wishart, D. S.; Knox, C.; Guo, A. C.; Shrivastava, S.; Hassanali, M.; Stothard, P.; Chang, Z.; Woolsey, J., DrugBank: a comprehensive resource for in silico drug discovery and exploration. Nucleic acids research 2006, 34, (Database issue), D668-72.

53. Thorn, C. F.; Klein, T. E.; Altman, R. B., PharmGKB: the Pharmacogenomics Knowledge Base. Methods in molecular biology 2013, 1015, 311-20.

54. Ferreira, W. A.; Araujo, M. D.; Anselmo, N. P.; de Oliveira, E. H.; Brito, J. R.; Burbano, R. R.; Harada, M. L.; Borges Bdo, N., Expression Analysis of Genes Involved in the RB/E2F Pathway in Astrocytic Tumors. PloS one 2015, 10, (8), e0137259.

55. Bustin, S. A.; Benes, V.; Garson, J. A.; Hellemans, J.; Huggett, J.; Kubista, M.; Mueller, R.; Nolan, T.; Pfaffl, M. W.; Shipley, G. L.; Vandesompele, J.; Wittwer, C. T., The MIQE guidelines: minimum information for publication of quantitative real-time PCR experiments. Clin Chem 2009, 55, (4), 611-22.

56. Livak, K. J.; Schmittgen, T. D., Analysis of relative gene expression data using real-time quantitative PCR and the 2(-Delta Delta C(T)) Method. Methods 2001, 25, (4), 402-8.

57. Cruvinel-Carloni, A.; da Silva-Oliveira, R. J.; Oliveira-Silva, V. A.; Rosa, M. N.; Bidinotto, L. T.; Berdinarelli, G. N.; Torrieri, R.; Evangelista, A. F.; Martinho, O. C.; Gonçalves, V. M., Abstract A29: Omics profile of two immortalized Brazilian glioblastoma cell cultures. In AACR: 2018.

58. Furgason, J. M.; Li, W.; Milholland, B.; Cross, E.; Li, Y.; McPherson, C. M.; Warnick, R. E.; Rixe, O.; Stambrook, P. J.; Vijg, J.; Bahassi el, M., Whole genome sequencing of glioblastoma multiforme identifies multiple structural variations involved in EGFR activation. Mutagenesis 2014, 29, (5), 341-50.

59. Cohen, A.; Sato, M.; Aldape, K.; Mason, C. C.; Alfaro-Munoz, K.; Heathcock, L.; South, S. T.; Abegglen, L. M.; Schiffman, J. D.; Colman, H., DNA copy number analysis of Grade IIIII and Grade IV gliomas reveals differences in molecular ontogeny including chromothripsis associated with IDH mutation status. Acta neuropathologica communications 2015, 3, 34.

60. Nicolaidis, S., Biomarkers of glioblastoma multiforme. Metabolism: clinical and experimental 2015, 64, (3 Suppl 1), S22-7.

61. Ramkissoon, S. H.; Bi, W. L.; Schumacher, S. E.; Ramkissoon, L. A.; Haidar, S.; Knoff, D.; Dubuc, A.; Brown, L.; Burns, M.; Cryan, J. B.; Abedalthagafi, M.; Kang, Y. J.; Schultz, N.; Reardon, D. A.; Lee, E. Q.; Rinne, M. L.; Norden, A. D.; Nayak, L.; Ruland, S.; Doherty, L. M.; LaFrankie, D. C.; Horvath, M.; Aizer, A. A.; Russo, A.; Arvold, N. D.; Claus, E. B.; AlMefty, O.; Johnson, M. D.; Golby, A. J.; Dunn, I. F.; Chiocca, E. A.; Trippa, L.; Santagata, S.; Folkerth, R. D.; Kantoff, P.; Rollins, B. J.; Lindeman, N. I.; Wen, P. Y.; Ligon, A. H.; Beroukhim, R.; Alexander, B. M.; Ligon, K. L., Clinical implementation of integrated whole-genome copy number and mutation profiling for glioblastoma. Neuro-oncology 2015, 17, (10), 1344-55.

62. Burbulis, I. E.; Wierman, M. B.; Wolpert, M.; Haakenson, M.; Lopes, M. B.; Schiff, D.; Hicks, J.; Loe, J.; Ratan, A.; McConnell, M. J., Improved molecular karyotyping in glioblastoma. Mutation research 2018, 811, 16-26.

63. Squire, J. A.; Arab, S.; Marrano, P.; Bayani, J.; Karaskova, J.; Taylor, M.; Becker, L.; Rutka, J.; Zielenska, M., Molecular cytogenetic analysis of glial tumors using spectral karyotyping and comparative genomic hybridization. Molecular diagnosis : a journal 
devoted to the understanding of human disease through the clinical application of molecular biology 2001, 6, (2), 93-108.

64. Venkatraj, V. S.; Begemann, M.; Sobrino, A.; Bruce, J. N.; Weinstein, I. B.; Warburton, D., Genomic changes in glioblastoma cell lines detected by comparative genomic hybridization. Journal of neuro-oncology 1998, 36, (2), 141-8.

65. Heim, S.; Mandahl, N.; Jin, Y.; Stromblad, S.; Lindstrom, E.; Salford, L. G.; Mitelman, F., Trisomy 7 and sex chromosome loss in human brain tissue. Cytogenetics and cell genetics 1989, 52, (3-4), 136-8.

66. Yurov, Y. B.; lourov, I. Y.; Vorsanova, S. G.; Liehr, T.; Kolotii, A. D.; Kutsev, S. I.; Pellestor, F.; Beresheva, A. K.; Demidova, I. A.; Kravets, V. S.; Monakhov, V. V.; Soloviev, I. V., Aneuploidy and confined chromosomal mosaicism in the developing human brain. PloS one 2007, 2, (6), e558.

67. Schrock, E.; Blume, C.; Meffert, M. C.; du Manoir, S.; Bersch, W.; Kiessling, M.; Lozanowa, T.; Thiel, G.; Witkowski, R.; Ried, T.; Cremer, T., Recurrent gain of chromosome arm 7q in low-grade astrocytic tumors studied by comparative genomic hybridization. Genes, chromosomes \& cancer 1996, 15, (4), 199-205.

68. Paulus, W.; Bayas, A.; Ott, G.; Roggendorf, W., Interphase cytogenetics of glioblastoma and gliosarcoma. Acta neuropathologica 1994, 88, (5), 420-5.

69. Jenkins, R. B.; Kimmel, D. W.; Moertel, C. A.; Schultz, C. G.; Scheithauer, B. W.; Kelly, P. J.; Dewald, G. W., A cytogenetic study of 53 human gliomas. Cancer genetics and cytogenetics 1989, 39, (2), 253-79.

70. Kim, D. H.; Mohapatra, G.; Bollen, A.; Waldman, F. M.; Feuerstein, B. G., Chromosomal abnormalities in glioblastoma multiforme tumors and glioma cell lines detected by comparative genomic hybridization. International journal of cancer 1995, 60, (6), 812-9.

71. Canello, T.; Shahar, T.; Zelikovitch, B.; Mordechai, A.; Lossos, A.; Lavon, I., GENO23AMPLIFICATION OF CHROMOSOME Xq11. 1-Xq11. 2 MIGHT PLAY A ROLE IN GLIOBLASTOMA. Neuro-oncology 2015, 17, (Suppl 5), v96.

72. Bae, N.; Gao, M.; Li, X.; Premkumar, T.; Sbardella, G.; Chen, J.; Bedford, M. T., A transcriptional coregulator, SPIN.DOC, attenuates the coactivator activity of Spindlin1. The Journal of biological chemistry 2017, 292, (51), 20808-20817.

73. Di Oto, E.; Biserni, G. B.; Varga, Z.; Morandi, L.; Cucchi, M. C.; Masetti, R.; Foschini, M. P., $X$ chromosome gain is related to increased androgen receptor expression in male breast cancer. Virchows Archiv : an international journal of pathology 2018, 473, (2), 155-163.

74. Chaligne, R.; Popova, T.; Mendoza-Parra, M. A.; Saleem, M. A.; Gentien, D.; Ban, K.; Piolot, T.; Leroy, O.; Mariani, O.; Gronemeyer, H.; Vincent-Salomon, A.; Stern, M. H.; Heard, E., The inactive $X$ chromosome is epigenetically unstable and transcriptionally labile in breast cancer. Genome research 2015, 25, (4), 488-503.

75. Di Oto, E.; Monti, V.; Cucchi, M. C.; Masetti, R.; Varga, Z.; Foschini, M. P., X chromosome gain in male breast cancer. Human pathology 2015, 46, (12), 1908-12.

76. Li, X.; Song, N.; Liu, L.; Liu, X.; Ding, X.; Song, X.; Yang, S.; Shan, L.; Zhou, X.; Su, D.; Wang, Y.; Zhang, Q.; Cao, C.; Ma, S.; Yu, N.; Yang, F.; Wang, Y.; Yao, Z.; Shang, Y.; Shi, L., USP9X regulates centrosome duplication and promotes breast carcinogenesis. Nature communications 2017, 8, 14866.

77. Park, S. C.; Hwang, U. K.; Ahn, S. H.; Gong, G. Y.; Yoon, H. S., Genetic changes in bilateral breast cancer by comparative genomic hybridisation. Clinical and experimental medicine 2007, 7, (1), 1-5.

78. Thakur, A.; Rahman, K. W.; Wu, J.; Bollig, A.; Biliran, H.; Lin, X.; Nassar, H.; Grignon, D. J.; Sarkar, F. H.; Liao, J. D., Aberrant expression of X-linked genes RbAp46, Rsk4, and Cldn2 in breast cancer. Molecular cancer research : MCR 2007, 5, (2), 171-81. 
79. Yamamoto, K.; Nagata, K.; Kida, A.; Hamaguchi, H., Acquired gain of an X chromosome as the sole abnormality in the blast crisis of chronic neutrophilic leukemia. Cancer genetics and cytogenetics 2002, 134, (1), 84-7.

80. McDonald, H. L.; Gascoyne, R. D.; Horsman, D.; Brown, C. J., Involvement of the $X$ chromosome in non-Hodgkin lymphoma. Genes, chromosomes \& cancer 2000, 28, (3), 246-57.

81. Younes, A.; Jendiroba, D.; Katz, R.; Hill, D.; Cabanillas, F.; Andreeff, M., Chromosome X numerical abnormalities in patients with non-Hodgkin's lymphoma. A study of 59 patients using fluorescence in situ hybridization. Cancer genetics and cytogenetics 1995, 82, (1), 23-9.

82. Brown, J. A.; Anderl, K. L.; Borell, T. J.; Qian, J.; Bostwick, D. G.; Jenkins, R. B., Simultaneous chromosome 7 and 17 gain and sex chromosome loss provide evidence that renal metanephric adenoma is related to papillary renal cell carcinoma. The Journal of urology 1997, 158, (2), 370-4.

83. Kuroda, N.; Shiotsu, T.; Hes, O.; Michal, M.; Shuin, T.; Lee, G. H., Acquired cystic disease-associated renal cell carcinoma with gain of chromosomes 3,7 , and 16, gain of chromosome X, and loss of chromosome Y. Medical molecular morphology 2010, 43, (4), 231-4.

84. Qu, X.; Jeldres, C.; Glaskova, L.; Friedman, C.; Schroeder, S.; Nelson, P. S.; Porter, C.; Fang, M., Identification of Combinatorial Genomic Abnormalities Associated with Prostate Cancer Early Recurrence. The Journal of molecular diagnostics : JMD 2016, 18, (2), 215-24.

85. Zhao, J.; Cheng, F.; Wang, Y.; Arteaga, C. L.; Zhao, Z., Systematic Prioritization of Druggable Mutations in approximately 5000 Genomes Across 16 Cancer Types Using a Structural Genomics-based Approach. Molecular \& cellular proteomics : MCP 2016, 15, (2), 642-56.

86. Nguyen, H. S.; Shabani, S.; Awad, A. J.; Kaushal, M.; Doan, N., Molecular Markers of Therapy-Resistant Glioblastoma and Potential Strategy to Combat Resistance. International journal of molecular sciences 2018, 19, (6).

87. Gamazon, E. R.; Stranger, B. E., The impact of human copy number variation on gene expression. Briefings in functional genomics 2015, 14, (5), 352-7.

88. Ali Hassan, N. Z.; Mokhtar, N. M.; Kok Sin, T.; Mohamed Rose, I.; Sagap, I.; Harun, R.; Jamal, R., Integrated analysis of copy number variation and genome-wide expression profiling in colorectal cancer tissues. PloS one 2014, 9, (4), e92553.

89. Zhang, Y.; Xue, Q.; Pan, G.; Meng, Q. H.; Tuo, X.; Cai, X.; Chen, Z.; Li, Y.; Huang, T.; Duan, X.; Duan, $Y$. Integrated Analysis of Genome-Wide Copy Number Alterations and Gene Expression Profiling of Lung Cancer in Xuanwei, China. PloS one 2017, 12, (1), e0169098.

90. Yan, D.; Yi, S.; Chiu, W. C.; Qin, L. G.; Kin, W. H.; Kwok Hung, C. T.; Linxiao, H.; Wai, C. K.; $\mathrm{Yi}$, S.; Tao, Y.; Tao, T., Integrated analysis of chromosome copy number variation and gene expression in cervical carcinoma. Oncotarget 2017, 8, (65), 108912-108922.

91. Vazquez-Mena, O.; Medina-Martinez, I.; Juarez-Torres, E.; Barron, V.; Espinosa, A.; Villegas-Sepulveda, N.; Gomez-Laguna, L.; Nieto-Martinez, K.; Orozco, L.; RomanBasaure, E.; Munoz Cortez, S.; Borges Ibanez, M.; Venegas-Vega, C.; Guardado-Estrada, M.; Rangel-Lopez, A.; Kofman, S.; Berumen, J., Amplified genes may be overexpressed, unchanged, or downregulated in cervical cancer cell lines. PloS one 2012, 7, (3), e32667.

92. Chen, Y.; McGee, J.; Chen, X.; Doman, T. N.; Gong, X.; Zhang, Y.; Hamm, N.; Ma, X.; Higgs, R. E.; Bhagwat, S. V.; Buchanan, S.; Peng, S. B.; Staschke, K. A.; Yadav, V.; Yue, Y.; Kouros-Mehr, $H_{.}$, Identification of druggable cancer driver genes amplified across TCGA datasets. PloS one 2014, 9, (5), e98293. 
93. Ohshima, K.; Hatakeyama, K.; Nagashima, T.; Watanabe, Y.; Kanto, K.; Doi, Y.; Ide, T.; Shimoda, Y.; Tanabe, T.; Ohnami, S.; Ohnami, S.; Serizawa, M.; Maruyama, K.; Akiyama, Y.; Urakami, K.; Kusuhara, M.; Mochizuki, T.; Yamaguchi, K., Integrated analysis of gene expression and copy number identified potential cancer driver genes with amplification-dependent overexpression in 1,454 solid tumors. Scientific reports 2017, 7, (1), 641.

94. Zhao, S.; Sedwick, D.; Wang, Z., Genetic alterations of protein tyrosine phosphatases in human cancers. Oncogene 2015, 34, (30), 3885.

95. Brognard, J.; Hunter, T., Protein kinase signaling networks in cancer. Current opinion in genetics \& development 2011, 21, (1), 4-11.

96. Wang, Z.; Shen, D.; Parsons, D. W.; Bardelli, A.; Sager, J.; Szabo, S.; Ptak, J.; Silliman, N.; Peters, B. A.; van der Heijden, M. S., Mutational analysis of the tyrosine phosphatome in colorectal cancers. Science 2004, 304, (5674), 1164-1166.

97. Lui, V. W. Y.; Peyser, N. D.; Ng, P. K.-S.; Hritz, J.; Zeng, Y.; Lu, Y.; Li, H.; Wang, L.; Gilbert, B. R.; General, I. J., Frequent mutation of receptor protein tyrosine phosphatases provides a mechanism for STAT3 hyperactivation in head and neck cancer. Proceedings of the National Academy of Sciences 2014, 111, (3), 1114-1119.

98. Veeriah, S.; Brennan, C.; Meng, S.; Singh, B.; Fagin, J. A.; Solit, D. B.; Paty, P. B.; Rohle, D.; Vivanco, I.; Chmielecki, J., The tyrosine phosphatase PTPRD is a tumor suppressor that is frequently inactivated and mutated in glioblastoma and other human cancers. Proceedings of the National Academy of Sciences 2009, 106, (23), 9435-9440.

99. Hamaoka, Y.; Negishi, M.; Katoh, H., Tyrosine kinase activity of EphA2 promotes its S897 phosphorylation and glioblastoma cell proliferation. Biochemical and biophysical research communications 2018, 499, (4), 920-926.

100. Burgoyne, A. M.; Palomo, J. M.; Phillips-Mason, P. J.; Burden-Gulley, S. M.; Major, D. L.; Zaremba, A.; Robinson, S.; Sloan, A. E.; Vogelbaum, M. A.; Miller, R. H., PTP $\mu$ suppresses glioma cell migration and dispersal. Neuro-oncology 2009, 11, (6), 767-778.

101. Ulbricht, U.; Brockmann, M. A.; Aigner, A.; Eckerich, C.; Müller, S.; Fillbrandt, R.; Westphal, M.; Lamszus, K., Expression and function of the receptor protein tyrosine phosphatase $\zeta$ and its ligand pleiotrophin in human astrocytomas. Journal of Neuropathology \& Experimental Neurology 2003, 62, (12), 1265-1275.

102. Akasaki, Y.; Liu, G.; Matundan, H. H.; Ng, H.; Yuan, X.; Zeng, Z.; Black, K. L.; Yu, J. S., A peroxisome proliferator-activated receptor-gamma agonist, troglitazone, facilitates caspase- 8 and -9 activities by increasing the enzymatic activity of protein-tyrosine phosphatase-1B on human glioma cells. The Journal of biological chemistry 2006, 281, (10), 6165-74.

103. Klingler-Hoffmann, M.; Fodero-Tavoletti, M. T.; Mishima, K.; Narita, Y.; Cavenee, W. K.; Furnari, F. B.; Huang, H. J.; Tiganis, T., The protein tyrosine phosphatase TCPTP suppresses the tumorigenicity of glioblastoma cells expressing a mutant epidermal growth factor receptor. The Journal of biological chemistry 2001, 276, (49), 46313-8.

104. Foehr, E. D.; Lorente, G.; Vincent, V.; Nikolich, K.; Urfer, R., FAS associated phosphatase (FAP-1) blocks apoptosis of astrocytomas through dephosphorylation of FAS. Journal of neuro-oncology 2005, 74, (3), 241-8.

105. Lomonaco, S. L.; Kahana, S.; Blass, M.; Brody, Y.; Okhrimenko, H.; Xiang, C.; Finniss, S.; Blumberg, P. M.; Lee, H. K.; Brodie, C., Phosphorylation of protein kinase Cdelta on distinct tyrosine residues induces sustained activation of Erk1/2 via down-regulation of MKP-1: role in the apoptotic effect of etoposide. The Journal of biological chemistry 2008, 283, (25), 17731-9.

106. Tanuma, N.; Nomura, M.; Ikeda, M.; Kasugai, I.; Tsubaki, Y.; Takagaki, K.; Kawamura, T.; Yamashita, Y.; Sato, I.; Sato, M.; Katakura, R.; Kikuchi, K.; Shima, H., Protein phosphatase Dusp26 associates with KIF3 motor and promotes N-cadherin-mediated cell-cell adhesion. Oncogene 2009, 28, (5), 752-61. 
107. Ortiz, B.; Fabius, A. W.; Wu, W. H.; Pedraza, A.; Brennan, C. W.; Schultz, N.; Pitter, K. L.; Bromberg, J. F.; Huse, J. T.; Holland, E. C.; Chan, T. A., Loss of the tyrosine phosphatase PTPRD leads to aberrant STAT3 activation and promotes gliomagenesis. Proceedings of the National Academy of Sciences of the United States of America 2014, 111, (22), 8149-54.

108. Chan, T. A.; Heguy, A., The protein tyrosine phosphatase receptor D, a broadly inactivated tumor suppressor regulating STAT function. Cell cycle 2009, 8, (19), 3063-4.

109. Choy, C. T.; Kim, H.; Lee, J. Y.; Williams, D. M.; Palethorpe, D.; Fellows, G.; Wright, A. J.; Laing, K.; Bridges, L. R.; Howe, F. A.; Kim, S. H., Anosmin-1 contributes to brain tumor malignancy through integrin signal pathways. Endocrine-related cancer 2014, 21, (1), 85-99.

110. Bae, W. K.; Hong, C. S.; Park, M. R.; Sun, E. G.; Lee, J. H.; Kang, K.; Ryu, K. H.; Shim, H. J.; Hwang, J. E.; Cho, S. H.; Chung, I. J., TAp73 inhibits cell invasion and migration by directly activating KAl1 expression in colorectal carcinoma. Cancer Lett 2018, 415, 106116.

111. Qi, L.; Zhang, W.; Cheng, Z.; Tang, N.; Ding, Y., Study on molecular mechanism of ANOS1 promoting development of colorectal cancer. PloS one 2017, 12, (8), e0182964.

112. Baysan, M.; Woolard, K.; Cam, M. C.; Zhang, W.; Song, H.; Kotliarova, S.; Balamatsias, D.; Linkous, A.; Ahn, S.; Walling, J.; Belova, G. I.; Fine, H. A., Detailed longitudinal sampling of glioma stem cells in situ reveals Chr7 gain and Chr10 loss as repeated events in primary tumor formation and recurrence. International journal of cancer 2017, 141, (10), 2002-2013.

113. Ozawa, T.; Riester, M.; Cheng, Y. K.; Huse, J. T.; Squatrito, M.; Helmy, K.; Charles, N.; Michor, F.; Holland, E. C., Most human non-GCIMP glioblastoma subtypes evolve from a common proneural-like precursor glioma. Cancer cell 2014, 26, (2), 288-300.

114. Johnson, A.; Severson, E.; Gay, L.; Vergilio, J. A.; Elvin, J.; Suh, J.; Daniel, S.; Covert, M.; Frampton, G. M.; Hsu, S.; Lesser, G. J.; Stogner-Underwood, K.; Mott, R. T.; Rush, S. Z.; Stanke, J. J.; Dahiya, S.; Sun, J.; Reddy, P.; Chalmers, Z. R.; Erlich, R.; Chudnovsky, Y.; Fabrizio, D.; Schrock, A. B.; Ali, S.; Miller, V.; Stephens, P. J.; Ross, J.; Crawford, J. R.; Ramkissoon, S. H., Comprehensive Genomic Profiling of 282 Pediatric Low- and HighGrade Gliomas Reveals Genomic Drivers, Tumor Mutational Burden, and Hypermutation Signatures. The oncologist 2017, 22, (12), 1478-1490.

115. Duan, Q. L.; Nikpoor, B.; Dube, M. P.; Molinaro, G.; Meijer, I. A.; Dion, P.; Rochefort, D.; Saint-Onge, J.; Flury, L.; Brown, N. J.; Gainer, J. V.; Rouleau, J. L.; Agostoni, A.; Cugno, M.; Simon, P.; Clavel, P.; Potier, J.; Wehbe, B.; Benarbia, S.; Marc-Aurele, J.; Chanard, J.; Foroud, T.; Adam, A.; Rouleau, G. A., A variant in XPNPEP2 is associated with angioedema induced by angiotensin I-converting enzyme inhibitors. American journal of human genetics 2005, 77, (4), 617-26.

116. Cheng, T.; Wei, R.; Jiang, G.; Zhou, Y.; Lv, M.; Dai, Y.; Yuan, Y.; Luo, D.; Ma, D.; Li, F.; Xi, L., XPNPEP2 is overexpressed in cervical cancer and promotes cervical cancer metastasis. Tumour biology : the journal of the International Society for Oncodevelopmental Biology and Medicine 2017, 39, (7), 1010428317717122.

117. Morishita, H.; Yagi, T., Protocadherin family: diversity, structure, and function. Current opinion in cell biology 2007, 19, (5), 584-92.

118. Berx, G.; van Roy, F., Involvement of members of the cadherin superfamily in cancer. Cold Spring Harbor perspectives in biology 2009, 1, (6), a003129.

119. van Roy, F., Beyond E-cadherin: roles of other cadherin superfamily members in cancer. Nature reviews. Cancer 2014, 14, (2), 121-34.

120. Blanco, P.; Sargent, C. A.; Boucher, C. A.; Mitchell, M.; Affara, N. A., Conservation of $P C D H X$ in mammals; expression of human $X / Y$ genes predominantly in brain. Mammalian genome : official journal of the International Mammalian Genome Society 2000, 11, (10), 906-14. 
121. Terry, S.; Maille, P.; Baaddi, H.; Kheuang, L.; Soyeux, P.; Nicolaiew, N.; Ceraline, J.; Firlej, V.; Beltran, H.; Allory, Y.; de la Taille, A.; Vacherot, F., Cross modulation between the androgen receptor axis and protocadherin-PC in mediating neuroendocrine transdifferentiation and therapeutic resistance of prostate cancer. Neoplasia 2013, 15, (7), 761-72.

122. Yang, X.; Chen, M. W.; Terry, S.; Vacherot, F.; Chopin, D. K.; Bemis, D. L.; Kitajewski, J.; Benson, M. C.; Guo, Y.; Buttyan, R., A human- and male-specific protocadherin that acts through the wnt signaling pathway to induce neuroendocrine transdifferentiation of prostate cancer cells. Cancer research 2005, 65, (12), 5263-71. 